\title{
FOREIGN DIRECT INVESTMENT \\ AND THE EQUITY HOME BIAS PUZZLE
}

\section{0}

BANCODEESPAÑA

Eurosistema

Documentos de Trabajo

N. ${ }^{\circ} 2008$

Sven Blank, Mathias Hoffmann and Moritz A. Roth 
FOREIGN DIRECT INVESTMENT AND THE EQUITY HOME

BIAS PUZZLE $\left.{ }^{*}\right)$

\section{Sven Blank and Mathias Hoffmann ${ }^{(*)}$}

DEUTSCHE BUNDESBANK

Moritz A. Roth ${ }^{(* *)}$

BANCO DE ESPAÑA

${ }^{(*}$ The views expressed in this paper are those of the authors and do not necessarily reflect those of the Deutsche Bundesbank, the Banco de España or the Eurosystem. We would like to thank seminar participants at the Banco de España and an anonymous referee for their comments, as well as Masashige Hamano for sharing his codes with us.

$\left.{ }^{(*}\right)$ Deutsche Bundesbank, Research Centre, Frankfurt am Main, Germany.

$\left.{ }^{\star \star \star}\right)$ Banco de España, Madrid, Spain, corresponding author: moritz.roth@bde.es.

Documentos de Trabajo. N. ${ }^{\circ} 2008$ 
The Working Paper Series seeks to disseminate original research in economics and finance. All papers have been anonymously refereed. By publishing these papers, the Banco de España aims to contribute to economic analysis and, in particular, to knowledge of the Spanish economy and its international environment.

The opinions and analyses in the Working Paper Series are the responsibility of the authors and, therefore, do not necessarily coincide with those of the Banco de España or the Eurosystem.

The Banco de España disseminates its main reports and most of its publications via the Internet at the following website: http://www.bde.es.

Reproduction for educational and non-commercial purposes is permitted provided that the source is acknowledged.

(C) BANCO DE ESPAÑA, Madrid, 2020

ISSN: 1579-8666 (on line) 


\section{Abstract}

The vast macroeconomic literature trying to explain the widely observed equity home bias disregards internationally active firms. In a DSGE model that features the endogenous choice of firms to become internationally active through either exports or foreign direct investment (FDI), we find that the optimal equity holdings of agents are biased towards domestic firms. Our finding indicates that international diversification is not as bad as empirical measures of the equity home bias suggest.

Keywords: country portfolios, multinational firms, international diversification, international trade, foreign direct investment.

JEL classification: F12, F21, F23, F41, G11. 


\section{Resumen}

La extensa literatura macroeconómica que pretende explicar el ampliamente observado equity home bias ignora a las empresas internacionalmente activas. En un modelo DSGE que presenta la elección endógena de las empresas de ser activas internacionalmente - ya sea a través de las exportaciones o por medio de la inversión extranjera directa (IED) - , encontramos que las tenencias de capital óptimas de los agentes están sesgadas hacia las empresas nacionales. Nuestro hallazgo indica que la diversificación internacional no es tan negativa como sugieren las medidas empíricas del equity home bias.

Palabras clave: carteras de los países, empresas multinacionales, diversificación internacional, comercio internacional, inversión extranjera directa.

Códigos JEL: F12, F21, F23, F41, G11. 


\section{Introduction}

How does the degree of internationalization of a country's firms influence the equity investment choices of its households, and how does it affect the widely observed equity home bias? Focusing on an individual household, investing in an internationally active domestic firm is more attractive than investing in a firm that is solely domestically active. The reason is that the revenue stream of internationally active firms is less prone to countryspecific economic conditions and thus provides a higher diversification benefit. Note that this argument only involves portfolio diversification through holding equities of different types of domestic firms, neglecting the possibility of obtaining portfolio diversification by holding equity of foreign firms. Most economic work on international portfolio choice and its empirical patterns exclusively focuses on the latter portfolio diversification motive and disregards indirect diversification through internationally active domestic firms. In this paper, we give a more diverse picture of different internationalization strategies for firms and show their implications for the optimal portfolio choice of households. We model two internationalization strategies, namely exporting and foreign direct investment (FDI). Those strategies are fundamentally different in the sense that a firm serving foreign markets through exporting only sustains all of its production facilities in its country of residence, while a firm serving the foreign market through FDI sets up production plants in the foreign countries it serves. An FDI firm thus becomes directly prone to the economic conditions in the host countries, while an export firm is only indirectly affected by these conditions through the foreign countries' demand for its domestically produced products. We are focussing on the consequences of these two different strategies for the equity home bias puzzle. It is a well established empirical fact that individuals all over the world hold large fractions of their wealth in assets of their own country. To show the empirical magnitude of this phenomenon, we use a standard measure for equity home bias, see e.g. Coeurdacier and Rey (2013), which we calculate for country $i$ as

Equity Home Bias in Country $i=1-\frac{\text { Share of Foreign Equities in Country } i \text { 's Equity Holdings }}{\text { Share of Foreign Equities in the World Market Portfolio }}$

Table 1 documents the equity home bias, as well as measures of multinational firm activity for selected advanced economies for the year 2016 based on information from the Coordinated Portfolio Investment Survey (CPIS) and the World Development Indicators (WDI) provided by the IMF and the World Bank, respectively. The equity home bias shown in the second column of Table 1 ranges from 0.69 for Japan to 0.41 for Germany. These figures are slightly smaller in magnitude compared to those reported in Coeurdacier and Rey (2013) for Japan, Switzerland and the United States for 2008, indicating a further decrease in equity home bias that the authors document for the years prior to 2008. However, despite the decline the equity home bias remains sizable.

In order to link the observed equity home bias at the country-level to multinational activity, we resort to the OECD's Analytical Database on Individual Multinationals and their Affiliates (ADIMA), which is a newly constructed database that aims at providing a multinational parent-affiliate register as well as a series of economic indicators. ADIMA 
Table 1 - Equity Home Bias and Multinational Activity

\begin{tabular}{|c|c|c|c|c|}
\hline \multirow{2}{*}{ Country } & \multirow{2}{*}{$\begin{array}{c}\text { Equity } \\
\text { Home Bias }\end{array}$} & \multicolumn{2}{|c|}{ Multinational Activity } & \multirow{2}{*}{$\begin{array}{c}\text { Number of } \\
\text { Underlying } \\
\text { MNEs }\end{array}$} \\
\hline & & $\begin{array}{l}\text { Average Share of } \\
\text { Domestic Sales }\end{array}$ & $\begin{array}{c}\text { Average Number of } \\
\text { Host Countries }\end{array}$ & \\
\hline Japan & 0.69 & 0.52 & 23.17 & 12 \\
\hline France & 0.58 & 0.31 & 40.20 & 5 \\
\hline United States & 0.58 & 0.59 & 33.21 & 39 \\
\hline Switzerland & 0.48 & 0.02 & 89.33 & 3 \\
\hline Germany & 0.41 & 0.26 & 59.70 & 10 \\
\hline
\end{tabular}

Notes: This Table shows equity home bias and multinational activity for selected economies in 2016. Equity home bias was calculated using information from the Coordinated Portfolio Investment Survey (CPIS) and the World Development Indicators (WDI) provided by the IMF and the World Bank, respectively. Information on multinational activity was taken from the Analytical Database on Individual Multinationals and their Affiliates (ADIMA) provided by the OECD.

currently covers 100 of the world's largest multinational enterprises based on total revenues in 2016. A prerequisite for being included in the database is a listing on a stock exchange. See OECD (2018) for a description and methodological details.

In column three to five of Table 1 we show the average share of domestic sales of the largest multinational enterprises residing in each country, the average number of host countries with operating affiliates, and the underlying number of multinational enterprises, respectively. Given our selection of countries, column 5 shows that we are covering 69 of the 100 largest firms covered in ADIMA. ${ }^{1}$ The average share of sales from operations abroad amounts to 41 percent for multinationals headquartered in the United States and to 98 percent for multinationals headquartered in Switzerland. The average number of host countries ranges from 23.17 for Japan to almost 90 for Swiss multinationals. ${ }^{2}$ This spread of sales around the globe shows the geographical diversification of these large firms' real activity and casts doubt on a dominating impact of domestic shocks on country portfolios featuring home bias. ${ }^{3}$

Parts of the literature on the home equity bias suggest that its observation constitutes evidence that households do not diversify optimally (e.g. Baxter and Jermann (1997)), others try to rationalize the observation through specific economic channels (e.g. Obstfeld and Rogoff (2001), Heathcote and Perri (2013)). In this paper, we allow for the possibility

\footnotetext{
${ }^{1}$ See the Appendix 7.1 for a list of these companies for each headquarter country.

${ }^{2}$ Note that host countries for some affiliates are unassigned in ADIMA (see the OECD (2018), for drawbacks in harmonising reporting requirements and standards). Hence, the reported averages of host countries should be seen as a lower bound.

${ }^{3}$ Though beyond the scope of our analysis, further diversification of regional shocks within a host country could also be achieved through the presence of several affiliates. On average, Japanese multinationals have 81.77 operating affiliates while German parent firms control 491.26 affiliates. The average number of affiliates per host country ranges from 2.91 (Japan) to 7.19 (France). As with the number of host countries, these numbers represent a lower bound.
} 
to obtain international diversification indirectly by investing in domestic multinational firms. We can therefore provide an explanation for why it might be optimal for agents to bias their equity holdings towards domestic firms, instead of diversifying their equity holding internationally. Based on this, we argue that the empirical measure of home bias is underestimating the true international diversification of households as it does not take into account indirect diversification through internationally active firms. Empirically, Cai and Warnock (2012) show the relevance of this channel for the US. They find that indirect diversification accounts for approximately $25 \%$ of the US equity home bias. Our contribution is that we investigate the effects of internationalization strategies on optimal portfolio choice of households in a theoretical framework which enables us to shed light on the mechanisms at work for different internationalization strategies. We assess the effects of introducing the possibility for firms to either tap foreign markets by exporting their products or by setting up foreign affiliates through foreign direct investment (FDI). We find that, due to the higher production diversification possibilities in the model with FDI, the average domestic firm is indeed less prone to country-specific shocks, giving a better hedge against these shocks than in a model with international trade only. Thus, given a standard calibration the home bias in optimal portfolio positions is higher if we allow for FDI.

Our work builds upon two strands of the literature. First, the literature on the home equity bias puzzle that started with Lucas (1982). Second, the literature on international trade with heterogeneous firms building on Melitz (2003). Lucas (1982) investigates a twocountry endowment economy with a single consumption good in which both countries are hit by independently and identically distributed dividend shocks. Perfect risk-sharing in this economy is achieved if all agents hold a percentage of their wealth in the stock of a given country which is equal to the relative size of its market capitalization. ${ }^{4}$ The fact that empirical evidence suggests that agents hold a substantially higher share in domestic equity constitutes the original equity home bias puzzle and can be interpreted as evidence for a lack of international diversification. Since then, numerous attempts have been made to explain or rationalize this empirical finding. The second substantial contribution to the literature has been made by Baxter and Jermann (1997). Essentially, they add labor income to Lucas' one-good model and find that in order to hedge against labor income risk it is optimal for agents to short home equity and to take up large long positions in foreign equity. Thus in their model the discrepancy between theoretically optimal and observed diversification is even higher than in Lucas (1982), indicating that the international diversification puzzle is even worse than previously thought. A third fundamental contribution is Heathcote and Perri (2013) who investigate a two good production economy with labor and capital income and find that a standard international macroeconomic model building on Backus et al. (1992) can rationalize the equity home bias to a large extent. This is because in their

\footnotetext{
${ }^{4}$ In Lucas (1982) there are two symmetric countries, thus 50-50 portfolios are optimal.
} 
framework domestic equity is a good hedge against labor income risk. An extensive review of the home bias literature is given in Coeurdacier and Rey (2013).

The second relevant strand of literature on which this paper builds on is the workhorse model of international trade with heterogeneous firms by Melitz (2003), and its extension by Ghironi and Melitz (2005) who investigate macroeconomic fluctuations with heterogeneous firms. The main feature of these models is that they include endogenous selection into international trade and can therefore replicate the observed differences in firm-specific productivity between exporters and non-exporters. In these papers, firms have an individual and heterogeneous productivity which they draw from an exogenously given Paretodistribution. If firms are productive enough, they are able to afford the fixed costs to enter foreign markets as well as the shipping costs to export their product to these markets. Helpman et al. (2004) extend the Melitz (2003) model by the possibility for firms to serve the foreign market by horizontal FDI. Foreign affiliates are costly to set up, operate with the firm-specific productivity of their parent firm, but hire local production factors in the host economy. In line with the empirical evidence only the most productive firms engage in FDI. Contessi (2010) incorporates horizontal FDI in the model of Ghironi and Melitz (2005) to investigate its implications for macroeconomic fluctuations. To investigate the impact of FDI activity on international asset positions, we extend the Ghironi and Melitz (2005) model by FDI, international bonds, as well as international equity holdings. The introduction of horizontal foreign direct investment follows the style of Helpman et al. (2004) and Contessi (2010). Hamano (2015) investigates the hedging of variety risk in a Ghironi and Melitz (2005) type economy with international bond and equity markets. His paper is our orientation point for the asset structure in our model. Recently, Ghironi and Wolfe (2018) show that in a model without trade in goods and through production diversification alone, domestic agents that have fully home biased portfolios can still obtain perfect risk-sharing as profits of firms engaged in FDI behave identically to diversified portfolios.

We contribute to both strands of the literature. By introducing horizontal FDI in a model of heterogeneous firms and international portfolio choice we are able to thoroughly investigate the real link between different internationalization strategies of firms and the portfolio decisions of households. This theoretical foundation allows us to evaluate how the measure of the home equity bias should be adjusted to account for non-diversified versus diversified investments.

The paper is structured as follows. Section 2 introduces the model, section 3 explains the intuition behind the optimal portfolio solutions resulting from the model. Section 4 gives the numerical parameterization of the model and outlines the solution method used. Section 5 presents the optimal numerical portfolio solutions obtained from the model, as well as a range of robustness exercises with respect to crucial model parameters. Section 6 concludes. 


\section{The model}

The model consists of two countries, Home (H) and Foreign (F). If not stated otherwise, foreign variables are indicated by an asterisk. First, in section 2.1 we turn to the households' optimization problems, in section 2.2 before we have a detailed look at the structure of the firms' sector.

\subsection{Households}

The representative households in Home maximizes its expected stream of utility from consumption $C_{t}$ and labor $L_{t}$,

$$
E_{t} \sum_{s=t}^{\infty} \beta_{s-t} U_{t}\left(C_{t}, L_{t}\right),
$$

where the utility function takes the CRRA form

$$
U_{t}\left(C_{t}, L_{t}\right)=\frac{C_{t}^{1-\gamma}}{1-\gamma}-\chi \frac{L_{t}^{1+\frac{1}{\varphi}}}{1+\frac{1}{\varphi}}
$$

with the coefficient of relative risk aversion $\gamma(\leq 1) . \quad \chi(>0)$ represents the dis-utility of supplying labor $L_{t}(\in[0,1])$ and $\varphi(\geq 0)$ is the Frisch elasticity of supplying labor. ${ }^{5} \beta_{t}$ is the endogenous discount factor and evolves as follows

$$
\beta_{t+1}=\beta_{t} \Upsilon\left(C_{t}\right), \text { with } \beta_{0}=1
$$

The functional form of $\Upsilon\left(C_{t}\right)$ is

$$
\Upsilon\left(C_{t}\right)=\bar{\beta} C_{t}^{-\nu}
$$

where $0 \leq \nu<\gamma$ and $0<\bar{\beta} C^{-\nu}<1$. Including an endogenous discount factor with $\Upsilon^{\prime}\left(C_{t}\right)<0$ guarantees the stationarity of the model including net foreign asset dynamics as pointed out by Schmitt-Grohe and Uribe (2003). $C_{t}$ is assumed to be a nested CES aggregator of goods that are produced domestically by home firms $C_{H, t}$, imported goods

\footnotetext{
${ }^{5}$ With $\varphi=\infty$ marginal disutility of labor is constant at $\chi$. With $\varphi=0$ it becomes infinite and labor supply becomes inelastic. Following Hamano (2015) in the calibration disutility will be increasing in the labor supplied.
} 
that are produced abroad by Foreign firms $C_{X, t}$ and goods that are domestically produced by affiliates of Foreign firms $C_{I, t}$ :

$$
C_{t}=\left[\alpha_{1}^{\frac{1}{\omega}} C_{H, t}^{1-\frac{1}{\omega}}+\alpha_{2}^{\frac{1}{\omega}} C_{X, t}^{1-\frac{1}{\omega}}+\left(1-\alpha_{1}-\alpha_{2}\right)^{\frac{1}{\omega}} C_{I, t}^{1-\frac{1}{\omega}}\right]^{\frac{1}{1-\frac{1}{\omega}}}
$$

In this definition, the $\alpha$ 's give different weights to the three distinct good categories, i.e. home produced goods, imported goods and goods produced in the domestic economy by affiliates of foreign firms. The nested CES structure is commonly used in international macroeconomic models with portfolio choice, since it gives a natural notion of home bias in consumption (see for instance Obstfeld and Rogoff (2001) and van Wincoop and Warnock (2010)). Because in these models there are only domestically produced and imported goods, the weights represent the home bias in consumption directly. In the case of FDI, there are three types of goods entering the aggregator representing a weight on domestically produced goods $\alpha_{1}$, imported goods $\alpha_{2}$ and goods produced by affiliates of foreign multinationals at Home $\left(1-\alpha_{1}-\alpha_{2}\right)$. To interpret the weights in a similar way as in a two good model, we assume that FDI goods are interpreted by agents as domestic goods. This implies that households care more about where a good is produced than about the origin of the firm producing the good. Thus, $\left(1-\alpha_{2}\right)$ is the measure of the home bias in consumption in our model. ${ }^{6} 7$ The consumption goods, $C_{H, t}, C_{X, t}$ and $C_{I, t}$ are themselves consumption baskets of varieties within the classified categories of domestic, imported and FDI goods. They are defined as

$$
\begin{aligned}
C_{H, t} & =V_{H, t}\left(\int_{\zeta \in \Omega} c_{D, t}(\zeta)^{1-\frac{1}{\sigma}} d \zeta\right)^{\frac{1}{1-\frac{1}{\sigma}}}, \\
C_{X, t} & =V_{X, t}^{*}\left(\int_{\vartheta \in \Omega} c_{X, t}(\vartheta)^{1-\frac{1}{\sigma}} d \vartheta\right)^{\frac{1}{1-\frac{1}{\sigma}}}, \\
C_{I, t} & =V_{I, t}^{*}\left(\int_{\varphi \in \Omega} c_{I, t}(\varphi)^{1-\frac{1}{\sigma}} d \varphi\right)^{\frac{1}{1-\frac{1}{\sigma}}},
\end{aligned}
$$

where $V_{H, t} \equiv N_{D, t}^{\psi-\frac{1}{\sigma-1}}, V_{X, t}^{*} \equiv N_{X, t}^{* \psi-\frac{1}{\sigma-1}}$ and $V_{I, t}^{*} \equiv N_{I, t}^{* \psi-\frac{1}{\sigma-1}}$ introduce a love of variety following Benassy (1996). $N_{D, t}, N_{X, t}^{*}$ and $N_{I, t}^{*}$ denote the number of domestic, imported and FDI goods that are available in the Home economy.

\subsubsection{Optimal consumption and price indices}

From the nested CES demand structure, the optimal consumption of domestic, imported and FDI baskets, as well as individual varieties, that are produced domestically by domestic

\footnotetext{
${ }^{6}$ Note however that this is a pure interpretation choice motivating the calibration of $\alpha_{1}$ and $\alpha_{2}$ later on, it does not have any effect on the model setup.

${ }^{7}$ In section 5.1 we provide a sensitivity analysis of the model results with respect to the parameters $\alpha_{1}$ and $\alpha_{2}$.
} 
firms, imported from foreign firms and produced domestically by affiliates of foreign firms can be derived as

$$
\begin{aligned}
& C_{H, t}=\left(\frac{P_{H, t}}{P_{t}}\right)^{-\omega} \alpha_{1} C_{t}, \\
& C_{X, t}=\left(\frac{P_{X, t}}{P_{t}}\right)^{-\omega} \alpha_{2} C_{t}, \\
& C_{I, t}=\left(\frac{P_{I, t}}{P_{t}}\right)^{-\omega}\left(1-\alpha_{1}-\alpha_{2}\right) C_{t} \\
& c_{D, t}(\zeta)=V_{H, t}^{\sigma-1}\left(\frac{p_{D, t}(\zeta)}{P_{H, t}}\right)^{-\sigma} C_{H, t}, \\
& c_{X, t}(\vartheta)=V_{X, t}^{* \sigma-1}\left(\frac{p_{X, t}^{*}(\vartheta)}{P_{X, t}}\right)^{-\sigma} C_{X, t}, \\
& c_{I, t}(\varphi)=V_{I, t}^{* \sigma-1}\left(\frac{p_{I, t}^{*}(\varphi)}{P_{I, t}}\right)^{-\sigma} C_{I, t} .
\end{aligned}
$$

$p_{X, t}^{*}(\vartheta)$ denotes the price of exported goods from foreign and $p_{I, t}^{*}$ is the price domestic affiliates of foreign firms charge in the domestic market, both are denominated in Home currency. Price indices are given by

$$
\begin{aligned}
P_{t} & =\left[\alpha_{1} P_{H, t}^{1-\omega}+\alpha_{2} P_{X, t}^{1-\omega}+\left(1-\alpha_{1}-\alpha_{2}\right) P_{I, t}^{1-\omega}\right]^{\frac{1}{1-\omega}}, \\
P_{H, t} & =\frac{1}{V_{H, t}}\left(\int_{\zeta \in \Omega_{t}} p_{D, t}(\zeta)^{1-\sigma} d \zeta\right)^{\frac{1}{1-\sigma}}, \\
P_{X, t} & =\frac{1}{V_{X, t}^{*}}\left(\int_{\vartheta \in \Omega_{t}} p_{X, t}^{*}(\vartheta)^{1-\sigma} d \vartheta\right)^{\frac{1}{1-\sigma}}, \\
P_{I, t} & =\frac{1}{V_{I, t}^{*}}\left(\int_{\varphi \in \Omega_{t}} p_{I, t}^{*}(\varphi)^{1-\sigma} d \varphi\right)^{\frac{1}{1-\sigma}} .
\end{aligned}
$$

Note that the price indices fluctuate with changes in the extensive margin or number of varieties. This is because they are defined on a welfare basis in the model. The impact of extensive margins in price indices is greater, the higher the love for variety, $\psi$. Following 
Hamano (2015) we define the welfare-based consumer price index, $P_{t}$, as numeraire for the Home economy. Therefore, real prices are defined as

$$
\begin{aligned}
\varrho_{H, t} & \equiv \frac{P_{H, t}}{P_{t}}, \\
\varrho_{X, t} & \equiv \frac{P_{X, t}}{P_{t}}, \\
\varrho_{I, t} & \equiv \frac{P_{I, t}}{P_{t}}, \\
\rho_{D, t}(\zeta) & \equiv \frac{p_{D, t}(\zeta)}{P_{t}}, \\
\rho_{X, t}^{*}(\vartheta) & \equiv \frac{p_{X, t}^{*}(\vartheta)}{P_{t}}, \text { and } \\
\rho_{I, t}^{*}(\varphi) & \equiv \frac{p_{I, t}^{*}(\varphi)}{P_{t}} .
\end{aligned}
$$

Similar expressions hold for Foreign.

\subsection{Firms}

In the Home country, as well as in the Foreign country there is a continuum of firms. Each firm produces a unique variety of the consumption good with labor being the only production input. Firms are heterogeneous with respect to their individual idiosyncratic labor productivity level z. Furthermore, firms' labor productivity is dependent on an aggregate country-specific component $Z_{t}{ }^{8}$

\subsubsection{Entry into and exit from production}

Every period there is a mass of new entrants $N_{E, t}$. New entrants are ex-ante identical and face an entry cost $f_{E, t}$ in terms of effective labor. In terms of domestic consumption these costs are $\frac{w_{t} f_{E, t}}{Z_{E, t}}$, where $Z_{E, t}$ denotes the aggregate labor productivity level in the entry sector and $w_{t}$ is the real wage level. Firms finance these entry costs by issuing equity on the international financial markets.

Upon entering, firms draw their idiosyncratic productivity $z$ from a distribution $G(z)$ with support $\left[z_{\min }, \infty\right)$. Once drawn, this idiosyncratic productivity remains constant over the firm's lifetime. There is a time-to-build lag, as firms only start producing one period after their entry decision. As there are no fixed costs of production, all firms that enter produce in any subsequent period until they are hit by an exit shock. This exit shock can occur every period with a fixed probability of $\delta$ and is independent of the idiosyncratic

\footnotetext{
${ }^{8}$ For an individual firm, $z$ and $Z_{t}$ affect its productivity independently of each other. Thus, for instance the production of a domestic firm with individual productivity $z$ for the domestic market is $y_{t}=Z_{t} z l_{t}$, where $l_{t}$ is the labor of this firm.
} 
productivity parameter. The timing is such that the exit shock only hits at the very end of a given period, i.e. after the new entrants have decided to enter. This has two implications. First, a fraction $\delta$ of the new entrants will be forced to exit before they can actually start producing. The Home economy's law of motion for the number of producing firms in the current period is thus given by

$$
N_{D, t}=(1-\delta)\left(N_{D, t-1}+N_{E, t-1}\right) .
$$

Second, households that invested in these entrants will immediately lose the value of their investment. Because households cannot foresee which individual firms are hit by the exogenous exit shock, it is optimal for them to hold the same amount of shares in every potentially producing firm of a given country. Therefore, it is without loss of generality to assume that all firms of a given country are owned by a mutual fund in which the individual households can invest. On aggregate, firms will enter production as long as their expected profits from entering are at least zero. Because the average expected profit of the ex-ante identical firms is equal to their average share price $\tilde{v}^{s}$, firms will enter until

$$
\tilde{v}^{s}=\frac{w_{t} f_{E, t}}{Z_{E, t}}
$$

For Foreign firms similar conditions hold.

\subsubsection{Internationalization strategies}

Firms can produce for the home market and engage in international activity, either through exports or foreign direct investment (FDI). The two internationalization strategies differ in their cost structures. Exporters produce their goods in their domestic plants, using domestic resources. They face a fixed period-by-period entry cost to the foreign market $f_{X, t}$, generally interpreted as a cost to set up and maintain a distribution network for their products. Furthermore, export firms face an iceberg type shipping cost $\tau_{t} \geq 1$. In contrast, FDI firms set up production plants or affiliates in the foreign country and produce by using foreign labor input. Setting up and maintaining the foreign plant involves a period-byperiod fixed cost $f_{I, t}$ which is assumed to be higher than the exporting fixed cost $f_{X, t}$. The reason is, that these firms incur the same costs of maintaining a distribution network in addition to the costs of setting up their own plant. Therefore, on the one hand the fixed costs of FDI are higher than those of exporting, but on the other hand producing abroad saves FDI firms the variable shipping costs.

\subsubsection{Production, pricing and profits}

In order to evaluate whether or not it is useful for a firm with individual productivity $z$ to engage in exporting or FDI, the firm weighs the different types of costs against the 
potential revenues these activities generate. To investigate the cost side, it is useful not only to look at the production functions of the different plants ${ }^{9}$, but also at the number of goods the firm is able to supply to the consumers at Home and Foreign for a given amount of hired labor. The latter differs from the former because of potential shipping costs. For each unit of domestic labor input, a Home firm can supply $Z_{t} z$ units of its unique variety to the domestic agents and $\frac{Z_{t} z}{\tau_{t}}$ units to the foreign agent. Furthermore, a foreign affiliate of a domestic firm can supply $Z_{t}^{*} z$ units of the Home firm's variety to the foreign agents for each unit of foreign labor input. The total supply functions of a Home firm for each production type are given by

$$
\begin{aligned}
& y_{D, t}(z)=Z_{t} z l_{D, t}(z) \\
& y_{X, t}(z)=\frac{Z_{t} z}{\tau_{t}} l_{X, t}(z) \quad \text { if firm } z \text { exports } \\
& y_{I, t}(z)=Z_{t}^{*} z l_{I, t}^{*}(z) \quad \text { if firm } z \text { has an affiliate in the foreign country. }
\end{aligned}
$$

On the revenue side, firms are monopolistically competitive and face an individual downward sloping demand function with constant elasticity $\sigma$ in every market they serve. This induces the following profit maximizing real prices, where prices are denoted in terms of the Home country's consumption good:

$$
\begin{aligned}
\rho_{D, t}(z) & =\frac{\sigma}{\sigma-1} \frac{w_{t}}{Z_{t} z} \\
\rho_{X, t}(z) & =\frac{\tau_{t}}{Q_{t}} \frac{\sigma}{\sigma-1} \frac{w_{t}}{Z_{t} z} \quad \text { if firm } z \text { exports } \\
\rho_{I, t}(z) & =\frac{\sigma}{\sigma-1} \frac{w_{t}^{*}}{Z_{t}^{*} z} \quad \text { if firm } z \text { has an affiliate in the foreign country. }
\end{aligned}
$$

Here, $Q_{t}=\frac{\epsilon_{t} P_{t}^{*}}{P_{t}}$ is the real exchange rate converting prices denoted in Foreign consumption good terms into prices in Home consumption good terms. The nominal exchange rate $\epsilon$ can be assumed to be unity without loss of generality.

Putting the revenue and cost sides together, we obtain the profits an individual firm with productivity $z$ can generate from producing for the domestic market, from producing for exporting and through its foreign affiliates, respectively. They are:

$$
\begin{aligned}
d_{D, t} & =\frac{1}{\sigma} N_{D, t}^{\psi(\omega-1)-1} \rho_{D, t}(z)^{1-\omega} \alpha_{1} C_{t} \\
d_{X, t} & =\frac{1}{\sigma} Q_{t} N_{X, t}^{\psi(\omega-1)-1} \rho_{X, t}(z)^{1-\omega} \alpha_{2}^{*} C_{t}^{*}-\frac{w_{t} f_{X, t}}{Z_{t}} \quad \text { if firm } z \text { exports } \\
d_{I, t} & =Q_{t}\left[\frac{1}{\sigma} N_{I, t}^{\psi(\omega-1)-1} \rho_{I, t}(z)^{1-\omega}\left(1-\alpha_{1}-\alpha_{2}\right) C_{t}^{*}-\frac{w_{t}^{*} f_{I, t}^{*}}{Z_{t}^{*}}\right] \quad \text { if firm } z \text { engages in FDI. }
\end{aligned}
$$

\footnotetext{
${ }^{9}$ Generally a Home firm's production is $Z_{t} z l_{t}$ for a good produced at Home and $Z_{t}^{*} z l_{t}^{*}$ for goods produced by a potential affiliate.
} 
In the profit equation for FDI firms $f_{I, t}^{*}$ is the FDI entry cost to the foreign market that the domestic firm has to pay. Total profits of a firm can be decomposed into profits generated by domestic sales, exports and FDI activities. Thus $d_{t}(z)=d_{D, t}(z)+d_{X, t}(z)+d_{I, t}(z)$. All profits are denominated in terms of Home consumption good. Similar equations apply to the foreign producers.

\subsubsection{Firm averages}

The heterogeneous firms and the variety they produce are completely characterized by the firm specific average productivity levels. Defining a specific distribution from which firms draw their individual labor productivity, we can define three distinct average productivity levels: The average productivity of all firms that produce in the Home economy $\tilde{z}_{D}$, the average productivity of Home exporters $\tilde{z}_{X, t}$ and the average productivity of Home FDI firms $\tilde{z}_{I, t}$. Generally, they are given by

$$
\begin{gathered}
\tilde{z}_{D, t} \equiv\left[\int_{z_{\min }}^{\infty} z^{\sigma-1} d G(z)\right]^{\frac{1}{\sigma-1}}, \quad \tilde{z}_{X, t} \equiv\left[\frac{1}{G\left(z_{I, t}\right)-G\left(z_{X, t}\right)} \int_{z_{X, t}}^{z_{I, t}} z^{\sigma-1} d G(z)\right]^{\frac{1}{\sigma-1}}, \\
\tilde{z}_{I, t} \equiv\left[\frac{1}{1-G\left(z_{I, t}\right)} \int_{z_{I, t}}^{\infty} z^{\sigma-1} d G(z)\right]^{\frac{1}{\sigma-1}} .
\end{gathered}
$$

The variables $z_{X, t}$ and $z_{I, t}$ denote the productivity cutoff levels such that a given firm with productivity $z \geq z_{X, t}$ finds it profitable to export and a given firm with $z \geq z_{I, t}$ finds it profitable to engage in FDI. Due to the assumed cost structure it holds that $z_{I, t}>z_{X, t}$, such that there is a direct mapping from the drawn productivity to the production modes a firm engages in. The least productive firms only find production for the domestic market profitable, firms with intermediate productivity additionally serve the foreign market through exports and the firms with the highest firm-specific productivity engage in FDI instead of exporting. The cutoff levels vary depending on the economic situation in a given country and play a crucial role in the dynamics of the model economy. These levels are derived below using an assumption on the distribution of firm specific productivities.

Following Melitz (2003) and Ghironi and Melitz (2005), we assume the firm specific productivity to be drawn from a Pareto distribution, which they show matches the actual distribution of firm-specific productivity well. The cumulative distribution function is given by

$$
G(z)=1-\left(\frac{z_{\min }}{z}\right)^{k}
$$


where $z$ denotes a specific cutoff productivity level and $k(>\sigma-1)$ is a shaping parameter. From the distributional assumption, the geometric productivity averages in terms of the productivity cutoff levels can be derived as

$$
\begin{gathered}
\tilde{z}_{D, t}=\nabla^{\frac{1}{\sigma-1}} z_{m i n}, \quad \tilde{z}_{X, t}=\nabla^{\frac{1}{\sigma-1}}\left[\frac{z_{X, t}^{\sigma-1} z_{I, t}^{k}-z_{X, t}^{k} z_{I, t}^{\sigma-1}}{z_{I, t}^{k}-z_{X, t}^{k}}\right]^{\frac{1}{\sigma-1}} \\
\tilde{z}_{I, t}=\nabla^{\frac{1}{\sigma-1}} z_{I, t}, \quad \text { with } \quad \nabla=\frac{k}{k-(\sigma-1)} .
\end{gathered}
$$

Furthermore, the shares of exporters and FDI firms in the total number of domestic firms can be expressed as:

$$
\begin{aligned}
& \frac{N_{X, t}}{N_{D, t}}=\frac{\tilde{z}_{X, t}^{-k}-\tilde{z}_{I, t}^{-k}}{\left(z_{\text {min }}\right)^{-k}} \\
& \frac{N_{I, t}}{N_{D, t}}=\frac{\left(\tilde{z}_{I, t}\right)^{-k} \nabla^{\frac{k}{\theta-1}}}{\left(z_{\text {min }}\right)^{-k}} .
\end{aligned}
$$

Importantly, the distributional assumption allows us to calculate the cutoff levels of the individual productivities, for which firms break even when they consider to export or produce for the domestic economy only or when they consider to engage in FDI or to serve foreign markets only through exporting. Thus, firms with individual productivity equal to one of the cutoff levels are indifferent between exporting or not, or between setting up an affiliate or exporting, respectively.

The productivity level of the marginal FDI firm is implicitly defined such that

$$
z_{I, t}: \quad d_{I, t}=0 \Leftrightarrow Q_{t}\left[\frac{1}{\sigma} N_{I, t}^{\psi(\omega-1)-1} \rho_{I, t}(z)^{1-\omega}\left(1-\alpha_{1}-\alpha_{2}\right) C_{t}^{*}\right]=Q_{t} \frac{w_{t}^{*} f_{I, t}^{*}}{Z_{t}^{*}}
$$

This leads to a cutoff productivity of

$$
z_{I, t}=\frac{1}{\sigma-1} N_{I, t}^{\frac{1-\psi(\omega-1)}{\omega-1}}\left(\frac{w_{t}^{*} \sigma}{Z_{t}^{*}}\right)^{\frac{\omega}{\omega-1}}\left(\frac{f_{I, t}^{*}}{\left(1-\alpha_{1}-\alpha_{2}\right) C_{t}^{*}}\right)^{\frac{1}{\omega-1}} .
$$

Using this productivity cutoff level for FDI firms and keeping in mind that the definition of the average productivity level of all FDI firms is $\tilde{z}_{I, t}=\nabla^{\frac{1}{\sigma-1}} z_{I, t}$ we can determine the average profits of all domestic FDI firms from their FDI activity

$$
\tilde{d}_{I, t}=Q_{t}\left(\nabla^{\frac{1-\omega}{1-\sigma}}-1\right) \frac{w_{t}^{*}}{Z_{t}^{*}} f_{I, t}^{*}
$$


The productivity level of the marginal export firm is such that

$$
\begin{gathered}
z_{X, t}: \quad d_{X, t}=0 \Leftrightarrow \frac{1}{\sigma} Q_{t} N_{X, t}^{\psi(\omega-1)-1} \rho_{X, t}\left(z_{X, t}\right)^{1-\omega} \alpha_{2}^{*} C_{t}^{*}=\frac{w_{t} f_{X, t}}{Z_{t}} \\
z_{X, t}=\left(\frac{\sigma f_{X, t}}{\alpha_{2}^{*} C_{t}^{*}}\right)^{\frac{1}{\omega-1}}\left(\frac{w_{t}}{Q_{t} Z_{t}}\right)^{\frac{\omega}{\omega-1}} \tau_{t} \frac{\sigma}{\sigma-1} N_{X, t}^{\frac{1-\psi(\omega-1)}{\omega-1}} .
\end{gathered}
$$

Substituting in both the cutoff level of exporters $z_{X, t}$ and the cutoff level for FDI firms $z_{I, t}$ into the definition of the average productivity level of exporters yields

$$
\tilde{z}_{X, t}=\nabla^{\frac{1}{\sigma-1}} \frac{\sigma^{\frac{\omega}{\omega-1}}}{(\sigma-1)}\left(\frac{1}{C_{t}^{*}}\right)^{\frac{1}{\omega-1}} N_{X, t}^{\frac{(1-\psi(\omega-1))}{\omega-1}}\left(\frac{w_{t}}{Q_{t} Z_{t}}\right)^{\frac{\omega}{\omega-1}} \tau_{t}\left[K K_{t}\right]^{\frac{1}{\sigma-1}}
$$

where

$$
K K_{t}=\frac{\left(\frac{f_{X, t}}{\alpha_{2}^{*}}\right)^{\frac{k-\sigma+1}{1-\omega}}-\left[\left(T O L_{t}\right)^{\omega} \tau_{t}^{1-\omega}\left(\frac{f_{I, t}^{*}}{\left(1-\alpha_{1}-\alpha_{2}\right)}\right)\left(\frac{N_{X, t}}{N_{I, t}}\right)^{(\psi(\omega-1)-1)}\right]^{\frac{k-\sigma+1}{1-\omega}}}{\left(\frac{f_{X, t}}{\alpha_{2}^{*}}\right)^{\frac{k}{1-\omega}}-\left[\left(T O L_{t}\right)^{\omega}\left(\frac{f_{I, t}^{*}}{1-\alpha_{1}^{*}-\alpha_{2}^{*}}\right) \tau_{t}^{1-\omega}\left(\frac{N_{X, t}}{N_{I, t}}\right)^{(\psi(\omega-1)-1)}\right]^{\frac{k}{1-\omega}}} .
$$

with $T O L_{t}=\left(\frac{w_{t}}{Z_{t} Q_{t}}\right)^{-1}\left(\frac{w_{t}^{*}}{Z_{t}^{*}}\right)$ being the terms of labor. This implies average profits of exporting firms of

$\left.\tilde{d}_{X, t}=\left[\left(\nabla \frac{\left(\frac{f_{X, t}}{\alpha_{2}^{*}}\right)^{\frac{k-\sigma+1}{1-\omega}}-\left[\left(T O L_{t}\right)^{\omega} \tau_{t}^{1-\omega}\left(\frac{f_{I, t}^{*}}{1-\alpha_{1}^{*}-\alpha_{2}^{*}}\right)\left(\frac{N_{X, t}}{N_{I, t}}\right)^{(\psi(\omega-1)-1)}\right]^{\frac{k-\sigma+1}{1-\omega}}}{\left(\frac{f_{X, t}}{\alpha_{2}^{*}}\right)^{\frac{k}{1-\omega}}-\left[\left(T O L_{t}\right)^{\omega}\left(\frac{f_{I, t}^{*}}{1-\alpha_{1}^{*}-\alpha_{2}^{*}}\right) \tau_{t}^{1-\omega}\left(\frac{N_{X, t}}{N_{I, t}}\right)^{(\psi(\omega-1)-1)}\right]^{\frac{k}{1-\omega}}}\right]\right) \alpha_{2}^{*}-f_{X, t}\right] \frac{w_{t}}{Z_{t}}$.

For Foreign an analogous expression holds. This completes the description of the firms.

\subsection{The asset market structure and the household's budget constraints}

The key to understanding the households' investment decisions in our model economy is the budget constraint of the Home and Foreign household. Its description gives us the 
opportunity to explain the asset market structure as well. The budget constraint of the Home representative household in terms of the Home consumption basket is given by

$$
\begin{aligned}
& C_{t}+s_{h, t+1} \tilde{v}_{t}^{s}\left(N_{D, t}+N_{E, t}\right)+s_{f, t+1} Q_{t} \tilde{v}_{t}^{s *}\left(N_{D, t}^{*}+N_{E, t}^{*}\right)+b_{h, t+1} v_{t}^{b}+b_{f, t+1} Q_{t} v_{t}^{b *} \\
& =w_{t} L_{t}+s_{h, t} N_{D, t}\left(\tilde{v}_{t}^{s}+\tilde{d}_{t}\right)+s_{f, t} N_{D, t}^{*} Q_{t}\left(\tilde{v}_{t}^{s *}+\tilde{d}_{t}^{*}\right)+b_{h, t}\left(v_{t}^{b}+d_{t}^{b}\right)+b_{f, t} Q_{t}\left(v_{t}^{b *}+d_{t}^{b *}\right) .
\end{aligned}
$$

In essence, it has the usual interpretation that the Home household's consumption smoothing is restricted by its decision to split its income of the current period between consumption $C_{t}$ and different means of savings to carry over consumption to future periods. $w_{t}$ are real wages and $L_{t}$ is the labor supply of the household. Thus, $w_{t} L_{t}$ gives the income from supplying labor. $Q_{t}$ is the welfare based real exchange rate. It is defined as the welfare-based Foreign price index $P_{t}^{*}$ converted to Home currency by the nominal exchange rate $\epsilon_{t}$ and divided the welfare-based Home price index $P_{t}: Q_{t} \equiv\left(\epsilon_{t} P_{t}^{*}\right) / P_{t}$. $\epsilon$ can be assumed to be unity without loss of generality. Therefore, $Q_{t}$ is defined in terms of the Home consumption good and a rise in $Q_{t}$ constitutes a depreciation of the real exchange rate from the perspective of a Home country investor. The Home household can invest in shares of the Home or the Foreign mutual fund. The Home mutual fund owns all the shares of the domestic new entrants $N_{E, t}$, as well as all the Home firms that produce in the current period $N_{D, t}$. The Foreign mutual fund owns all the shares of the foreign new entrants $N_{E, t}^{*}$ as well as all currently producing Foreign firms $N_{D, t}^{*} \cdot s_{h, t+1}\left(s_{f, t+1}\right)$ denote the shares in the mutual fund of Home (Foreign) firms the Home household buys in the current period. $\tilde{v}_{t}^{s}\left(\tilde{v}_{t}^{s *}\right)$ is the real price of a Home (Foreign) mutual fund share denominated in Home (Foreign) consumption goods. Furthermore, the Home household can invest in bonds issued by Home and Foreign. $b_{h, t+1}$ and $b_{f, t+1}$ denote the amount of Home and Foreign bond bought by the Home household, respectively. $v_{t}^{b}$ and $v_{t}^{b *}$ are the real prices of bonds issued in Home and Foreign. $\tilde{d}_{t}$ and $\tilde{d}_{t}^{*}$ are the average real dividends of Home (Foreign) firms and $d_{t}^{b}$ and $d_{t}^{b *}$ are the real dividends of bonds issued in Home and Foreign. For a bond indexed by the welfare-based price index we have $d_{t}^{b}=d_{t}^{b *}=1$. For a bond indexed by the empirical CPI real dividends are given by $d_{t}^{b}=\frac{\hat{P}_{t+1}}{P_{t+1}}$ and $d_{t}^{b *}=\frac{\hat{P}_{t+1}^{*}}{P_{t+1}^{*}}$, where the empirical measure of CPI is denoted by $\hat{P}\left(\hat{P}^{*}\right)$. The interpretation of the pricing is that Home (Foreign) CPI indexed bonds give a nominal payoff of $\hat{P}\left(\hat{P}^{*}\right)$ units of Home (Foreign) currency next period. Since the rest of the variables in the budget constraint are deflated using the welfare-based price levels $P_{t}\left(P_{t}^{*}\right)$, the nominal payoff of $\hat{P}\left(\hat{P}^{*}\right)$ has to be divided by $P_{t}\left(P_{t}^{*}\right)$ to denote it in real terms. In Ghironi and Melitz (2005) the relation between the welfare-based and the empirical CPI measures is given by $P_{t}=N_{t}^{\frac{1}{1-\sigma}} \hat{P}_{t}$, with $N_{t}=N_{D, t}+N_{X, t}^{*}$, as the empirical measure usually does not account for the changes in the extensive margin, which influence the welfare-based CPI. 
The representative Foreign household maximizes its utility with respect to a symmetric real budget constraint denominated in Foreign consumption goods:

$$
\begin{aligned}
C_{t}^{*} & +s_{f, t+1}^{*} \tilde{v}_{t}^{s *}\left(N_{D, t}^{*}+N_{E, t}^{*}\right)+s_{h, t+1}^{*} Q_{t}^{-1} \tilde{v}_{t}^{s}\left(N_{D, t}+N_{E, t}\right)+b_{h, t+1}^{*} Q_{t}^{-1} v_{t}^{b}+b_{f, t+1}^{*} v_{t}^{b *} \\
& =w_{t}^{*} L_{t}^{*}+s_{f, t}^{*} N_{D, t}^{*}\left(\tilde{v}_{t}^{s *}+\tilde{d}_{t}^{*}\right)+s_{h, t}^{*} N_{D, t} Q_{t}^{-1}\left(\tilde{v}_{t}^{s}+\tilde{d}_{t}\right)+b_{h, t}^{*} Q_{t}^{-1}\left(v_{t}^{b}+d_{t}^{b}\right)+b_{f, t}^{*}\left(v_{t}^{b *}+d_{t}^{b *}\right) .
\end{aligned}
$$

\subsubsection{Households' optimality conditions}

Defining the returns on Home and Foreign equities as

$$
r_{h, t}^{s} \equiv(1-\delta) \frac{\tilde{v}_{t}^{s}+\tilde{d}_{t}}{\tilde{v}_{t-1}^{s}}, \quad r_{f, t}^{s} \equiv(1-\delta) \frac{\tilde{v}_{t}^{s *}+\tilde{d}_{t}^{*}}{\tilde{v}_{t-1}^{s *}} \frac{Q_{t}}{Q_{t-1}}
$$

respectively, and the return on the domestic bond as

$$
r_{h, t}^{b} \equiv \frac{v_{t}^{b}+d_{t}^{b}}{v_{t-1}^{b}}, \quad r_{f, t}^{b} \equiv \frac{v_{t}^{b *}+d_{t}^{b *}}{v_{t-1}^{b *}} \frac{Q_{t}}{Q_{t-1}}
$$

where the dividends paid by a regular bond are

$$
\begin{array}{rlrl}
d_{t}^{b} & =1, \quad d_{t}^{b *}=1, & & \text { for welfare-based bonds } \\
d_{t}^{b}=\frac{\hat{P}_{t+1}}{P_{t+1}}, \quad d_{t}^{b *}=\frac{\hat{P}_{t+1}^{*}}{P_{t+1}^{*}}, & & \text { for CPI indexed bonds }
\end{array}
$$

the first-order conditions of the household become

$$
\begin{gathered}
\chi L_{t}^{\frac{1}{\varphi}}=C_{t}^{-\gamma} w_{t} \\
1=\Upsilon\left(C_{t}\right) E_{t}\left\{\left(\frac{C_{t+1}}{C_{t}}\right)^{-\gamma} r_{h, t+1}^{s}\right\} \\
1=\Upsilon\left(C_{t}\right) E_{t}\left\{\left(\frac{C_{t+1}}{C_{t}}\right)^{-\gamma} r_{f, t+1}^{s}\right\} \\
1=\Upsilon\left(C_{t}\right) E_{t}\left\{\left(\frac{C_{t+1}}{C_{t}}\right)^{-\gamma} r_{h, t+1}^{b}\right\} \\
1=\Upsilon\left(C_{t}\right) E_{t}\left\{\left(\frac{C_{t+1}}{C_{t}}\right)^{-\gamma} r_{f, t+1}^{b}\right\} \\
C_{t}+s_{h, t+1} \tilde{v}_{t}^{s}\left(N_{D, t}+N_{E, t}\right)+s_{f, t+1} Q_{t} \tilde{v}_{t}^{s *}\left(N_{D, t}^{*}+N_{E, t}^{*}\right)+b_{h, t+1} v_{t}^{b}+b_{f, t+1} v_{t}^{b *} \\
=w_{t} L_{t}+s_{h, t} N_{D, t}\left(\tilde{v}_{t}^{s}+\tilde{d}_{t}\right)+s_{f, t} N_{D, t}^{*} Q_{t}\left(\tilde{v}_{t}^{s *}+\tilde{d}_{t}^{*}\right)+b_{h, t}\left(v_{t}^{b}+d_{t}^{b}\right)+b_{f, t}\left(v_{t}^{b *}+d_{t}^{b *}\right) .
\end{gathered}
$$


Using the same definitions of returns on home and foreign equities as above the first-order conditions of the Foreign household are

$$
\begin{gathered}
\chi L_{t}^{* \frac{1}{\varphi}}=C_{t}^{*-\gamma} w_{t}^{*} \\
1=\Upsilon\left(C_{t}^{*}\right) E_{t}\left[\left(\frac{C_{t+1}^{*}}{C_{t}^{*}}\right)^{-\gamma} r_{h, t+1}^{s} \frac{Q_{t}}{Q_{t+1}}\right] \\
1=\Upsilon\left(C_{t}^{*}\right) E_{t}\left[\left(\frac{C_{t+1}^{*}}{C_{t}^{*}}\right)^{-\gamma} r_{f, t+1}^{s} \frac{Q_{t}}{Q_{t+1}}\right] \\
1=\Upsilon\left(C_{t}^{*}\right) E_{t}\left[\left(\frac{C_{t+1}^{*}}{C_{t}^{*}}\right)^{-\gamma} r_{h, t+1}^{b} \frac{Q_{t}}{Q_{t+1}}\right] \\
1=\Upsilon\left(C_{t}^{*}\right) E_{t}\left[\left(\frac{C_{t+1}^{*}}{C_{t}^{*}}\right)^{-\gamma} r_{f, t+1}^{b} \frac{Q_{t}}{Q_{t+1}}\right] \\
C_{t}^{*}+s_{f, t+1}^{*} \tilde{v}_{t}^{s *}\left(N_{D, t}^{*}+N_{E, t}^{*}\right)+s_{h, t+1}^{*} Q_{t}^{-1} \tilde{v}_{t}^{s}\left(N_{D, t}+N_{E, t}\right)+b_{h, t+1}^{*} Q_{t}^{-1} v_{t}^{b}+b_{f, t+1}^{*} v_{t}^{b *} \\
=w_{t}^{*} L_{t}^{*}+s_{f, t}^{*} N_{D, t}^{*}\left(\tilde{v}_{t}^{s *}+\tilde{d}_{t}^{*}\right)+s_{h, t}^{*} N_{D, t} Q_{t}^{-1}\left(\tilde{v}_{t}^{s}+\tilde{d}_{t}\right)+b_{h, t}^{*} Q_{t}^{-1}\left(v_{t}^{b}+d_{t}^{b}\right)+b_{f, t}^{*}\left(v_{t}^{b *}+d_{t}^{b *}\right) .
\end{gathered}
$$

\subsection{Market Clearing}

In the model there are seven markets: Four asset markets, two labor markets and a good market. By Walras' law one of these market clearing conditions is implied by the other six and thus can be disregarded in the final system of equilibrium conditions.

\subsubsection{Asset Markets}

Following Hamano (2015) we assume that the equity supply of each individual firm is normalized to 1. Because households cannot foresee which individual firms are hit by the exogenous exit shock, they hold the same amount of shares in every potentially producing firm of a given country. Therefore, the home household's holdings in each home firm $s_{h, t+1}$ and the foreign household's holdings in each home firm $s_{h, t+1}^{*}$ have to sum to unity:

$$
s_{h, t+1}+s_{h, t+1}^{*}=1 \text {. }
$$

Analogously, the home household's holdings in each foreign firm $s_{f, t+1}$ and the foreign household's holdings in each foreign firm $s_{f, t+1}^{*}$ have to sum to unity:

$$
s_{f, t+1}+s_{f, t+1}^{*}=1 \text {. }
$$


Additionally, there are two international bond markets and those bonds are assumed to be in zero net supply:

$$
b_{h, t+1}+b_{h, t+1}^{*}=0
$$

and

$$
b_{f, t+1}+b_{f, t+1}^{*}=0 .
$$

\subsubsection{Labor market}

There are three separate sources of labor demand for production in each country. Home firms demand domestic labor $l_{D, t}$ for production to serve the domestic market and $l_{X, t}$ to serve the foreign market through exports. Furthermore, foreign firms serving the Home market through their affiliates demand $l_{I, t}$ units of domestic labor.

In addition to the use in production, firms hire labor in order to pay entry, export and FDI costs. Entering firms hire $\frac{N_{E, t} f_{E, t}}{Z_{E, t}}$ units of effective labor in total, domestic export firms $\frac{N_{X, t} f_{X, t}}{Z_{t}}$ and affiliates of foreign firms $\frac{N_{I, t}^{*} f_{I, t}}{Z_{t}}$.

Adding up all of these demand sources of the average firms and equating it to the labor supply of the representative household, the overall Home labor market clearing condition is

$$
L_{t}=\frac{(\sigma-1)}{w_{t}}\left[N_{D, t} \tilde{d}_{D, t}+N_{X, t} \tilde{d}_{X, t}+N_{I, t}^{*} Q_{t} \tilde{d}_{I, t}^{*}\right]+\frac{N_{E, t} f_{E, t}}{Z_{E, t}}+\frac{\sigma}{Z_{t}}\left[N_{X, t} f_{X, t}+N_{I, t}^{*} f_{I, t}\right] .
$$

For Foreign the condition is

$$
L_{t}^{*}=\frac{(\sigma-1)}{w_{t}^{*}}\left[N_{D, t}^{*} \tilde{d}_{D, t}^{*}+N_{X, t}^{*} \tilde{d}_{X, t}^{*}+N_{I, t} Q_{t}^{-1} \tilde{d}_{I, t}\right]+\frac{N_{E, t}^{*} f_{E, t}^{*}}{Z_{E, t}^{*}}+\frac{\sigma}{Z_{t}^{*}}\left[N_{X, t}^{*} f_{X, t}^{*}+N_{I, t} f_{I, t}^{*}\right] .
$$

\subsubsection{Good Market}

International good market clearing states that international consumption has to be equal to international labor and capital income, denoted in the Home consumption basket.

$$
C_{t}+Q_{t} C_{t}^{*}=Y_{t}+Q_{t} Y_{t}^{*}
$$

where

$$
\begin{aligned}
Y_{t} & =w_{t} L_{t}+N_{D, t} \tilde{d}_{t}-N_{E, t} \tilde{v}_{t}^{s} \\
Y_{t}^{*} & =w_{t}^{*} L_{t}^{*}+N_{D, t}^{*} \tilde{d}_{t}^{*}-N_{E, t}^{*} \tilde{v}_{t}^{s *} .
\end{aligned}
$$




\subsection{The stochastic processes of production}

The stochastic aggregate productivities and the productivities specific to the entry sector are assumed to be given by the following $\mathrm{AR}(1)$ processes:

$$
\begin{array}{r}
\log \left(Z_{t+1}\right)=\rho \log \left(Z_{t}\right)+\epsilon_{t+1} \\
\log \left(Z_{t+1}^{*}\right)=\rho \log \left(Z_{t}^{*}\right)+\epsilon_{t+1}^{*} \\
\log \left(Z_{E, t+1}\right)=\rho_{E} \log \left(Z_{E, t}\right)+\epsilon_{E, t+1} \\
\log \left(Z_{E, t+1}^{*}\right)=\rho_{E} \log \left(Z_{E, t}^{*}\right)+\epsilon_{E, t+1}^{*} .
\end{array}
$$

With 4 shocks and 4 assets that Home and Foreign households can invest in, we have complete markets in our model economy.

\subsection{Net foreign asset dynamics}

We can combine the two budget constraints of the households to obtain an expression for the net foreign asset dynamics of the Home economy:

$$
\begin{gathered}
s_{h, t+1} \tilde{v}_{t}^{s}\left(N_{D, t}+N_{E, t}\right)+s_{f, t+1} Q_{t} \tilde{v}_{t}^{s *}\left(N_{D, t}^{*}+N_{E, t}^{*}\right)+b_{h, t+1} v_{t}^{b}+b_{f, t+1} Q_{t} v_{t}^{b *} \\
=s_{h, t} N_{D, t}\left(\tilde{v}_{t}^{s}+\tilde{d}_{t}\right)+s_{f, t} N_{D, t}^{*} Q_{t}\left(\tilde{v}_{t}^{s *}+\tilde{d}_{t}^{*}\right)+b_{h, t}\left(v_{t}^{b}+d_{t}^{b}\right)+b_{f, t} Q_{t}\left(v_{t}^{b *}+d_{t}^{b *}\right) \\
+\frac{1}{2}\left(N_{E, t} \tilde{v}_{t}^{s}+Q_{t} N_{E, t}^{*} \tilde{v}_{t}^{s *}\right)-\frac{1}{2}\left(N_{D, t} \tilde{d}_{t}-Q_{t} N_{D, t}^{*} \tilde{d}_{t}^{*}\right)+\frac{1}{2}\left(w_{t} L_{t}-Q_{t} w_{t}^{*} L_{t}^{*}\right)-\frac{1}{2}\left(C_{t}-Q_{t} C_{t}^{*}\right) .
\end{gathered}
$$

This condition can be interpreted as an equation for the dynamics of the Home country's financial wealth.

\subsection{Equilibrium}

The equilibrium conditions are given by four of the first-order conditions for the Home household (28a - 28e), the equivalent equations for the Foreign household (29a - 29e), the aggregate accounting constraint (38), the 16 optimality conditions of the firm and the 12 optimal pricing and dividend conditions, the 6 clearing conditions for the Home and Foreign labor and asset markets in (2.4) and the definitions of equity returns (24), bond returns (25), the two definitions of the dividends of bonds (26), the definition of the terms of labor, the income (36b), as well as the stochastic processes (37). As mentioned above, the goods market clearing condition (36) is left out due to Walras' law. Theses are 58 equations, in 58 unknowns. The unknowns are $C_{t}, C_{t}^{*}, L_{t}, L_{t}^{*} s_{h, t}, s_{h, t}^{*}, s_{f, t}, s_{f, t}^{*}, b_{h, t}, b_{f, t}, b_{h, t}^{*}, b_{f, t}^{*} r_{h, t}^{s}, r_{f, t}^{s}$, $r_{h, t}^{b}, r_{f, t}^{b} \tilde{v}_{t}^{s}, \tilde{v}_{t}^{s *}, v_{t}^{b}, v_{t}^{b *}, d_{t}^{b}, d_{t}^{b *} Y_{t}, Y_{t}^{*}, w_{t}, w_{t}^{*}, d_{t}, d_{t}^{*}, N_{E, t}, N_{E, t}^{*}, \tilde{z}_{X, t}, \tilde{z}_{X, t}^{*}, \tilde{z}_{I, t}, \tilde{z}_{I, t}^{*}, N_{D, t}, N_{D, t}^{*}$, $N_{X, t}, N_{X, t}^{*}, N_{I, t}, N_{I, t}^{*}, Q_{t}, T O L_{t} \tilde{\rho}_{D, t}, \tilde{\rho}_{D, t}^{*}, \tilde{\rho}_{X, t}, \tilde{\rho}_{X, t}^{*}, \tilde{\rho}_{I, t}, \tilde{\rho}_{I, t}^{*}, \tilde{d}_{D, t}, \tilde{d}_{D, t}^{*}, \tilde{d}_{X, t}, \tilde{d}_{X, t}^{*} \tilde{d}_{I, t}, \tilde{d}_{I, t}^{*}$, and $Z_{t}, Z_{t}^{*}, Z_{E, t}, Z_{E, t}^{*}$. 


\section{Portfolio intuition}

Coeurdacier and Gourinchas (2011) derive general results for portfolio solutions in a complete markets economy like ours. We can use a linearized version of the real exchange rate and a static version of the household's budget constraint to obtain an intuition on how the household uses bonds and equity to hedge against exchange rate fluctuations and labor income risk.

\subsection{Welfare-based and CPI-indexed real exchange rate}

In general, the risk components in the welfare based real exchange rate in a model with a preference for variety of the Benassy (1996) type can be decomposed as

$$
\hat{Q}_{t}=\hat{q}_{t}+\psi R_{v, t}
$$

where $\psi$ is the 'love of variety' parameter, $\hat{q}_{t}$ is the linearized CPI based real exchange rate and $R_{v, t}$ is the risk component associated with the varieties.

The welfare-based real exchange rate in our model is

$$
\begin{aligned}
Q_{t} & =\frac{\epsilon_{t} P_{t}^{*}}{P_{t}} \\
& =\frac{\epsilon_{t}\left[\alpha_{1} N_{D, t}^{*-\psi(1-\omega)} \tilde{p}_{D, t}^{*(1-\omega)}+\alpha_{2} N_{X, t}^{-\psi(1-\omega)} \tilde{p}_{X, t}^{(1-\omega)}+\left(1-\alpha_{1}-\alpha_{2}\right) N_{I, t}^{-\psi(1-\omega)} \tilde{p}_{I, t}^{(1-\omega)}\right]^{\frac{1}{1-\omega}}}{\left[\alpha_{1} N_{D, t}^{-\psi(1-\omega)} \tilde{p}_{D, t}^{(1-\omega)}+\alpha_{2} N_{X, t}^{*-\psi(1-\omega)} \tilde{p}_{X, t}^{*(1-\omega)}+\left(1-\alpha_{1}-\alpha_{2}\right) N_{I, t}^{*-\psi(1-\omega)} \tilde{p}_{I, t}^{*(1-\omega)}\right]^{\frac{1}{1-\omega}}} .
\end{aligned}
$$

Without loss of generality, we assume that the nominal exchange rate $\epsilon_{t}=1$ in the remainder of the exposition, as it does not influence the results.

Log-linearizing around the steady-state yields

$$
\begin{aligned}
\hat{Q}_{t}=\left(1-2 S_{X D}\right) T \hat{O} L_{t}- & S_{X D} \hat{z}_{X}^{R}-\left(1-S_{D D}-S_{X D}\right) \hat{z}_{I}^{R}+\psi\left(S_{D D}-S_{X D}\right) \hat{N}_{D}^{R}-\psi\left(1-S_{D D}-S_{X D}\right) \hat{N}_{X}^{R} \\
& +\psi S_{X D}\left[\hat{N}_{D, t}^{R}-\hat{N}_{X, t}^{R}\right]+\psi\left(1-S_{D D}-S_{X D}\right)\left[\hat{N}_{X, t}^{R}-\hat{N}_{I, t}^{R}\right], \quad
\end{aligned}
$$

where $S_{D D}=\alpha_{1} \bar{\rho}_{H, t}^{1-\omega}, S_{X D}=\alpha_{2} \bar{\rho}_{X, t}^{1-\omega}, S_{N I}=\left(1-\alpha_{1}-\alpha_{2}\right) \bar{\rho}_{I, t}^{1-\omega}=\left(1-S_{D D}-S_{X D}\right)$. The first three terms denote the effects of changes in the terms of labor, relative FDI cutoffs and relative export cutoffs on $\hat{Q}_{t}$, respectively. The last four terms represent the effect of changes in the relative numbers of domestic, export and FDI varieties on the welfare-based real exchange rate.

The average terms of trade are related with the terms of labor as follows

$$
\operatorname{TOT}_{t}=\frac{\epsilon_{t} \tilde{p}_{X, t}}{\tilde{p}_{X, t}^{*}}=\frac{\tilde{z}_{X, t}^{*}}{\tilde{z}_{X, t}} T O L_{t}^{-1}
$$


Linearized this gives

$$
T \hat{O} T_{t}=-T \hat{O} L_{t}-\hat{z}_{X, t}^{R}
$$

Therefore, the linearized real exchange rate can be rewritten as

$$
\begin{aligned}
\hat{Q}_{t}=\left(2 S_{X D}-1\right) T \hat{O} T_{t} & -\left(1-S_{X D}\right) \hat{z}_{X, t}^{R}-\left(1-S_{D D}-S_{X D}\right) \hat{z}_{I}^{R}+\psi\left(S_{D D}-S_{X D}\right) \hat{N}_{D}^{R}-\psi\left(1-S_{D D}-S_{X D}\right) \hat{N}_{X}^{R} \\
& +\psi S_{X D}\left[\hat{N}_{D, t}^{R}-\hat{N}_{X, t}^{R}\right]-\psi\left(1-S_{D D}-S_{X D}\right)\left[\hat{N}_{I, t}^{R}-\hat{N}_{X, t}^{R}\right], \quad(42)
\end{aligned}
$$

The formula for the real exchange rate shows how deviations from the welfare-based PPP arise in a model with FDI. The first term $\left(2 S_{X D}-1\right) T \hat{O} T_{t}$ reflects changes in the terms of trade risk that constitute a consumption risk. When there is a home bias in consumption, $S_{X D}>\frac{1}{2}$, and the price of Foreign export goods in terms of the Home export goods rises, i.e. the terms of trade increase, the real exchange rate depreciates from the point of view of a Home investor. The second term $-\left(1-S_{X D}\right) \hat{z}_{X, t}^{R}$ reflects consumption risk induced by fluctuations of the price of non-traded goods between Home and Foreign, due to changes in the relative export cutoff levels between Home and Foreign. For example an increase in $\hat{z}_{X, t}^{R}$ means higher non-traded good inflation in Home than in Foreign and therefore an appreciation of the real exchange rate. The third term $-\left(1-S_{D D}-S_{X D}\right) \hat{z}_{I}^{R}$ reflects consumption risk induced by fluctuations of the price of affiliate produced versus traded goods between Home and Foreign. An increase in $\hat{z}_{I}^{R}$ means that relatively fewer Home firms will engage in FDI compared to Foreign firms and some firms will therefore switch their way of serving the foreign economy from FDI to exports. All other thing equal, this leads to a fall in the optimal average price charged by affiliates of Home firms in Foreign, which depresses the price level of Foreign relative to the price level in Home. Thus a rise in $\hat{z}_{I}^{R}$ causes an appreciation of the real exchange rate from the perspective of a Home investor. The fourth term $\psi\left(S_{D D}-S_{X D}\right) \hat{N}_{D}^{R}$ reflects variety risk with respect to the relative number of domestically available varieties. An increase in $\hat{N}_{D}^{R}$ means that a relatively higher number of domestically produced varieties is available at Home than in Foreign, leading to a depreciation of the real exchange rate if $\psi\left(S_{D D}-S_{X D}\right)>0$. This takes place as households value an increase of the variety choices in their consumption basket, thus the welfare in Home increases relative to the welfare in Foreign. At the same time, a higher number of varieties causes higher competition among varieties leading to a fall in the average domestic price level and thus a real depreciation of the welfare consistent real exchange rate. The fifth term $-\psi\left(1-S_{D D}-S_{X D}\right) \hat{N}_{X}^{R}$ represents variety risk with respect to the relative number of imported varieties and the sign of the influence on the real exchange rate is reversed in comparison to the domestic number of varieties. If more imported varieties are available in Home relative to Foreign, i.e. if $\hat{N}_{X}^{R}>0$, this pushes the Home price level up and thus appreciates the real exchange rate. The two last terms express the variety risk that materialises through relative changes in the number of domestic, imported and affiliate provided varieties. The sixth term $\psi S_{X D}\left[\hat{N}_{D, t}^{R}-\hat{N}_{X, t}^{R}\right]$ 
captures the relative changes in the number of imported varieties with respect to the solely domestically produced varieties. If $\hat{N}_{X, t}^{R}$ is decreasing, other things equal, a relatively higher number of imported varieties is available in Home in comparison to Foreign, which leads to falling average price of imported goods in Home and a real depreciation of the exchange rate from a Home perspective. The seventh term $-\psi\left(1-S_{D D}-S_{X D}\right)\left[\hat{N}_{I, t}^{R}-\hat{N}_{X, t}^{R}\right]$ captures a similar effect for changes in the relative number of affiliate provided varieties in comparison to imported varieties. If $\hat{N}_{I, t}^{R}$ increases, other thing equal this means that a relatively lower number of affiliate produced varieties is available in Home compared to imported varieties, leading to a rise in the Home price level and a appreciation of the real exchange rate.

As for instance in Ghironi and Melitz (2005) and Hamano (2015), the welfare-based price indices in our model fully reflect changes in varieties and this affects optimal portfolios if bonds are indexed by the welfare-based price indices. As Broda and Weinstein (2004) point out, in reality the CPI's do not adjust for changes in varieties. Therefore a more realistic assumption is that agents base their decisions on empirical versions of CPI indices and the real exchange rate. To extract the effect of changes in the number of varieties from bonds and the real exchange rate, Hamano (2015) defines the price indices in a way such that the empirical real exchange rate does not reflect these changes any more. For our model it becomes

$$
\hat{q}_{t}=\left(2 S_{X D}-1\right) T \hat{O} T_{t}-\left(1-S_{X D}\right) \hat{z}_{X, t}^{R}-\left(1-S_{D D}-S_{X D}\right) \hat{z}_{I}^{R} .
$$

\subsection{Portfolios from static budget constraint and complete asset markets}

We derive the intuition behind the optimal portfolios from a static version of the household's budget constraint. Expressing both the Home and Foreign budget constraints in terms of the Home consumption good, subtracting the Home from the Foreign constraint and $\log$ linearizing this equation yields

$\hat{P}_{t}+\hat{C}_{t}-\left(\hat{P}_{t}^{*}+\hat{C}_{t}^{*}\right)=S_{W}\left(\hat{w}_{t}^{R}+\hat{l}_{t}^{R}\right)+(2 s-1)\left[S_{D}\left(\hat{N}_{D, t}^{R}+\hat{\tilde{d}}_{t}^{R}\right)-S_{I}\left(\hat{N}_{E, t}^{R}+\hat{\tilde{v}}_{t}^{s R}\right)\right]+2 b^{\prime} \hat{d}_{t}^{b R}$,

with $S_{W} \equiv \frac{w}{C}, S_{D} \equiv \frac{N_{D} \tilde{d}}{C}$ and $S_{I} \equiv \frac{N_{E} \tilde{v}^{s}}{C}$ being the labor income, dividends and investments relative to consumption in the symmetric steady state, respectively. Bond holdings are multiplied by their dividend $d^{b}$ and normalized by steady state consumption $b^{\prime}=b d^{b} / C$. We use the following definitions $\hat{w}_{t}^{R}+\hat{l}_{t}^{R} \equiv \hat{w}_{t}+\hat{l}_{t}-\left(\hat{Q}_{t}+\hat{w}_{t}^{*}+\hat{l}_{t}^{*}\right), \hat{N}_{D, t}^{R}+\hat{\tilde{d}}_{t}^{R} \equiv \hat{N}_{D, t}+$ $\hat{\tilde{d}}_{t}-\left(\hat{N}_{D, t}^{*}+\hat{Q}_{t}+\hat{\tilde{d}}_{t}^{*}\right), \hat{N}_{E, t}^{R}+\hat{\tilde{v}}_{t}^{s R} \equiv \hat{N}_{E, t}+\hat{\tilde{v}}_{t}^{s}-\left(\hat{N}_{E, t}^{*}+\hat{Q}_{t}+\hat{\tilde{v}}_{t}^{s *}\right)$ and $\hat{d}_{t}^{b R} \equiv \hat{d}_{t}^{b}-\left(\hat{Q}_{t}+\right.$ $\left.\hat{d}_{t}^{b *}\right)$. The terms denote relative nominal labor income, relative average equity dividends, relative investment and relative bond dividends between Home and Foreign, respectively. Coeurdacier and Gourinchas (2011) find that for economies with complete asset markets, the portfolio solution of Devereux and Sutherland (2010) coincides with finding portfolios 
that replicate the complete market allocation, i.e. portfolios ensuring that the perfect risk-sharing condition

$$
\hat{P}_{t}+\hat{C}_{t}-\left(\hat{P}_{t}^{*}+\hat{C}_{t}^{*}\right)=-\left(1-\frac{1}{\gamma}\right) \hat{Q}_{t}
$$

is satisfied for arbitrary realizations of the stochastic shocks driving the economy. It is important to stress that in this setup the static budget constraint (44) is not equivalent to the period-by-period budget constraint (23). The static budget constraint does not capture the period-by-period dynamics and thus we cannot deduce that if (44) holds, (23) holds as well. Coeurdacier and Gourinchas (2011) derive their results for a case where they are both equivalent. Although this is not the case here, we still rely on the static budget constraint as we find it useful to derive households' hedging motives from it, keeping in mind that there might be other factors influencing the solution to the dynamic model which we obtain by numerical procedures. Since our model is relatively complex, obtaining the portfolio intuition from the static budget constraint instead of deriving closed-form solutions of the portfolios simplifies our solution procedure. We proceed by substituting in the perfect risk-sharing condition under complete asset markets in the linearized budget constraint above. This yields

$$
-\left(1-\frac{1}{\gamma}\right) \hat{Q}_{t}=S_{W} R_{w, t}+(2 s-1) R_{e, t}+2 b^{\prime} R_{b, t}
$$

with $R_{w, t} \equiv\left(\hat{w}_{t}^{R}+\hat{l}_{t}^{R}\right), R_{e, t} \equiv\left[S_{D}\left(\hat{N}_{D, t}^{R}+\hat{\tilde{d}}_{t}^{R}\right)-S_{I}\left(\hat{N}_{E, t}^{R}+\hat{\tilde{v}}_{t}^{s R}\right)\right]$ and $R_{b, t} \equiv \hat{d}_{t}^{b R}$.

\subsubsection{Portfolios}

We postulate the following loadings of equities and bonds on the risk components in $\hat{Q}_{t}$ :

$$
\begin{aligned}
T \hat{O}_{t} & =\phi_{T O T, b} R_{b, t}+\phi_{T O T, e} R_{e, t} \\
\hat{z}_{X, t}^{R} & =\phi_{Z X, b} R_{b, t}+\phi_{Z X, e} R_{e, t} \\
\hat{z}_{I, t}^{R} & =\phi_{Z I, b} R_{b, t}+\phi_{Z I, e} R_{e, t} \\
\hat{N}_{D, t}^{R} & =\phi_{N D, b} R_{b, t}+\phi_{N D, e} R_{e, t} \\
\hat{N}_{X, t}^{R} & =\phi_{N X, b} R_{b, t}+\phi_{N X, e} R_{e, t} \\
\hat{N}_{D, t}^{R}-\hat{N}_{X, t}^{R} & =\phi_{N D N X, b} R_{b, t}+\phi_{N D N X, e} R_{e, t} \\
\hat{N}_{I, t}^{R}-\hat{N}_{X, t}^{R} & =\phi_{N X N I, b} R_{b, t}+\phi_{N X N I, e} R_{e, t} .
\end{aligned}
$$

Similarly, the loadings of the assets on labor income risk are

$$
R_{w, t}=\phi_{w, b} R_{b, t}+\phi_{w, e} R_{e, t} .
$$


Substituting in this set of relations into (46), we can solve for the optimal portfolio positions that replicate the complete market allocation. Thus, the portfolio allocations we find imply that (46) holds for all possible realizations of the relative shocks $\left(\hat{Z}_{t}, \hat{Z}_{E, t}\right)$. As in Coeurdacier and Gourinchas (2011) agents use bonds to hedge all risks deriving from the real exchange rate, while they use equity to hedge those risks orthogonal to the real exchange rate.

Next we have to make some distinctions depending on the type of bonds that are traded in the model economy. If bonds perfectly load on the welfare-based real exchange rate and have returns $R_{b, t}=-\hat{Q}_{t}$ with dividends $d_{t}^{b}=d_{t}^{*}=1$, from above we have

$$
\hat{Q}_{t}=\left(2 S_{D I}-1\right) \phi_{T O T, e}+S_{N I} \phi_{N D I, e}+\left(1-S_{D I}\right) \phi_{N E X, e}+\psi\left(S_{D}-1\right) \phi_{I V, e}+\psi\left(S_{I}-1\right) \phi_{I D, e} .
$$

Therefore, if bonds perfectly hedge all variations in the number of firms and their offered varieties, the optimal portfolios become those given in Coeurdacier and Gourinchas (2011)

$$
\begin{aligned}
s & =\frac{1}{2}\left[1-S_{w} \phi_{w, e}\right], \\
b^{\prime} & =\frac{1}{2}\left[\left(1-\frac{1}{\gamma}\right)-S_{w} \phi_{w, b}\right] .
\end{aligned}
$$

Home bias in equities arises only because the real exchange rate does not fully hedge against labor income risk. If the partial correlation between relative labor income and relative equity returns $\phi_{w, e}$ is negative it is optimal for home agents to hold a home biased share portfolio. This is a standard result in the literature (e.g.Heathcote and Perri (2013)). Note, that the structure of the model can influence the partial correlation $\phi_{w, e}$, as well as the steady state ratio $S_{W}=w / c$ and therefore, the home bias in a model with FDI can differ from that in a model without FDI if there is a systematic way in which FDI activity influences these two numbers.

If bonds only hedge the CPI-based real exchange rate risk, i.e. $R_{b, t}=-\hat{q}_{t}$, the optimal portfolios become

$$
\begin{aligned}
s & =\frac{1}{2}\left[1-S_{w} \phi_{w, e}-\psi\left(1-\frac{1}{\gamma}\right)\left(\left(S_{D D}-S_{X D}\right) \phi_{N D, e}\right.\right. \\
& \left.\left.-\left(1-S_{D D}-S_{X D}\right) \phi_{N X, e}+S_{X D} \phi_{N D N X, e}-\left(1-S_{D D}-S_{X D}\right) \phi_{N I N X, e}\right)\right], \\
b^{\prime} & =\frac{1}{2}\left[\left(1-\frac{1}{\gamma}\right)-S_{w} \phi_{w, b}-\psi\left(1-\frac{1}{\gamma}\right)\left(\left(S_{D D}-S_{X D}\right) \phi_{N D, b}\right.\right. \\
& \left.\left.-\left(1-S_{D D}-S_{X D}\right) \phi_{N X, b}+S_{X D} \phi_{N D N X, b}-\left(1-S_{D D}-S_{X D}\right) \phi_{N I N X, b}\right)\right] .
\end{aligned}
$$


For comparison, the portfolios without FDI from Hamano (2015) are given by

$$
\begin{aligned}
& s=\frac{1}{2}\left[1-S_{w} \phi_{w, e}-\psi\left(1-\frac{1}{\gamma}\right)\left(\left(2 S_{E D}-1\right) \phi_{N D, e}+\left(1-S_{E D}\right) \phi_{N D N X, e}\right)\right], \\
& b^{\prime}=\frac{1}{2}\left[\left(1-\frac{1}{\gamma}\right)-S_{w} \phi_{w, b}-\psi\left(1-\frac{1}{\gamma}\right)\left(\left(2 S_{E D}-1\right) \phi_{N D, b}+\left(1-S_{E D}\right) \phi_{N D N X, b}\right)\right]
\end{aligned}
$$

where $S_{E D}=\alpha \rho_{H}^{1-\omega}$ and $\alpha$ is the home bias in production in Hamano's model, which is $1-\alpha_{2}$ in our model.

An intuition is that the firms on average become less prone to the country specific shock if some of them engage in FDI. Therefore, the correlation decreases, contributing to a larger home bias in equity holdings.

\section{Solution procedure and parametrization}

Ghironi and Melitz (2005) show that in models in which heterogeneous firms are characterized in the way we do it here, despite the very rich heterogeneity, macroeconomic fluctuations only depend on the average characteristics of the average domestic producer, the average exporter and the average FDI firm and the fluctuations in the cutoff levels. Therefore the model with heterogeneous firms is observationally equivalent to an economy with a representative firm that has a domestic branch, an export branch and an FDI branch and is adjusting the relative sizes of these branches depending on the shocks to the economy. This feature is very convenient since aggregation becomes easy and we are able to solve this heterogeneous agent model by perturbation methods.

Regular DSGE models are usually log-linearized around their non-stochastic steady-state and solved using an appropriate solution method (e.g. the method of undetermined coefficients, etc.). In models that include a country portfolio choice involving the possibility for the agents to invest in multiple assets, as in the model presented here, this approach becomes unfeasible. This is the case because up to a first-order approximation, the portfolio is indeterminate. In the non-stochastic steady-state, there is no uncertainty and portfolios with the same return do not pin down a unique portfolio choice. The same is true for a first-order approximation in which certainty equivalence holds and assets have to have the same expected payoff. The method developed by Devereux and Sutherland (2010, 2011) allows pinning down the steady-state portfolio choice uniquely by approximating the portfolio part of the model to the second order, while the rest of the model is approximated to the first order. Furthermore, the first-order dynamics of the portfolio choice can be pinned down using a third-order approximation of the portfolio part and a second-order approximation of the rest of the model. 
The parametrization of the model follows largely from Hamano (2015) and Contessi (2010) for the parts regarding foreign direct investment. The parameter governing relative risk aversion $\gamma$ is set to 2 . We interpret a period as a year and therefore set the discount factor $\beta$ equal to 0.96. As is standard in this literature, the lower bound of the Pareto distribution determining the individual firm productivities is set to 1 and the time endowment of workers is also set to 1 . The Frisch elasticity of labor supply is $\varphi=2$ and $\chi$ is calibrated such that in steady state the households' labor supplies are equal to 1 . Furthermore, we assume $k+1>\sigma$ to ensure that the scaling factor $\nabla=k /[k-(\sigma-1)]$ is positive. The shape parameter of the Pareto distribution $k$ determines the dispersion of individual firm productivities and is set to 3.4. The elasticity of substitution among varieties $\sigma$ is set to 3.8 and the elasticity of substitution between Home and Foreign goods $\omega$ is set to 2 . This induces firms to charge an average price mark-up of 35.7 percent above the average marginal costs. In the presence of fixed entry costs to production this is not as high as it might seem. Ghironi and Melitz (2005) calibrate the exit shock $\delta$ to match the ratio of job destruction in the US, which is 10 percent. This gives them a value of $\delta=0.1$. This parameter governs the ratio of entering to existing varieties $N_{E, t} / N_{D, t}$ in our model. The fixed entry cost to production is normalized to be $f_{E, t}=1$. The fixed costs of international activity $f_{X, t}$ and $f_{I, t}$ are set relative to $f_{E, t}$. Following Contessi (2010) the share of FDI firms in the total number of firms is calibrated using the fixed entry cost to FDI activity $f_{I, t}$. As him, we set $f_{I}$, to 28 percent of $\Theta f_{E, t}=0.0036$, which is the fixed cost of entering production of a new variety annualized. The fixed cost of exporting is set to about 10 percent of this annualized entry cost. Following Hamano (2015) we choose a preference for variety parameter $\psi=0.18$. For the preference weights of the different types of goods available in Home we assume $\alpha_{1}=0.7$ and $\alpha_{2}=0.15$. This also leaves the weight on goods produced by Foreign affiliates in Home $1-\alpha_{1}-\alpha_{2}=0.15$. Therefore, we assume equal preference weights on imported and affiliate provided goods. We moreover assume symmetric preference weights for Foreign consumers.

Like Hamano (2015) we take the shock processes from Coeurdacier et al. (2010). For annual data from 1984 to 2004, they estimate productivity processes for the G7 countries. The $\mathrm{AR}(1)$ process for our 4 shocks in matrix notation is

$$
Z_{t+1}=\Gamma Z_{t}+\epsilon_{t+1}
$$

where $Z_{t}=\left[\log \left(Z_{t}\right) \log \left(Z_{t}^{*}\right) \log \left(Z_{E, t}\right) \log \left(Z_{E, t}^{*}\right)\right]$ and $\epsilon_{t}=\left[\begin{array}{llll}\epsilon_{t} & \epsilon_{t}^{*} & \epsilon_{E, t} & \epsilon_{E, t}^{*}\end{array}\right]$. The matrix $\Gamma$ and the variance-covariance matrix $\Sigma$ of the innovations $\epsilon_{t}$ are assumed to be

$$
\Gamma=\left[\begin{array}{cccc}
0.75 & 0 & 0 & 0 \\
0 & 0.75 & 0 & 0 \\
0 & 0 & 0.79 & 0 \\
0 & 0 & 0 & 0.79
\end{array}\right]
$$


and

$$
\Sigma=\left[\begin{array}{cccc}
0.0096 & 0.0043 & 0 & 0 \\
0.0043 & 0.0096 & 0 & 0 \\
0 & 0 & 0.0199 & 0.0038 \\
0 & 0 & 0.0038 & 0.0199
\end{array}\right] \cdot{ }^{10}
$$

\section{Optimal portfolios with different internationalization strategies}

The results we obtain by applying the Devereux and Sutherland solution algorithm for our baseline calibration are given in Table 2.

Table 2 - Optimal Portfolios

\begin{tabular}{lcccc}
\hline \hline & Welfare RER & \multicolumn{3}{c}{ Empirical RER } \\
& Without FDI & With FDI & Without FDI & With FDI \\
\hline Equity & 1.14 & 1.86 & 1.56 & 1.83 \\
Bonds & 0.70 & 0.19 & 0.68 & 0.13 \\
\hline
\end{tabular}

The first two columns show the optimal equity and bond portfolios for our baseline model with bonds indexed by the welfare-based CPI, while the third and fourth column show the optimal portfolios in an economy with bonds indexed by the empirical CPI.

The very first column shows the optimal bond and equity portfolio holdings of the Home household in a model in which firms can only tap international markets by exporting. This setup, as well as the results shown are identical to Hamano (2015). The model produces a significant home bias in domestic equity holdings for all specifications. In fact, home households short foreign equity to take excessive long positions in domestic equity. With welfare-based bonds available, Home households optimally hold 114 percent of the shares of Home firms, while at the same time, they hold -14 percent of the shares of foreign firms, i.e. they increase their exposure to domestic equity by short-selling foreign equity. At the same time the Foreign household does the opposite trade and shorts home equity. Thus, this is a sustainable equilibrium outcome. The bond position is positive such that in order to hedge the real exchange rate risk, Home households save in domestic bonds and borrow abroad.

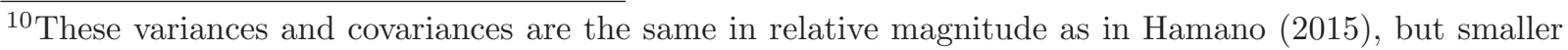
in absolute magnitude to ensure sensible simulation results, i.e. that for instance consumption is not negative after shocks. Since asset markets are complete, this does not affect the portfolio solutions.
} 
Qualitatively, the same is the case with bonds based on the empirical CPI in column 3 which shows that the optimal equity bias increases to 156 percent and bond positions decrease as the variety risk component drops out of the empirical real exchange rate and households have to hedge additional risk. ${ }^{11}$ Again this is identical to the model case shown in Hamano (2015).

In our model with FDI, the optimal share Home households hold in the equity issued by domestic firms amounts to 186 percent and is thus higher than in the comparable benchmark model without FDI. This is in line with our expectations that FDI increases a Home firms exposure to foreign country risk and therefore holdings of domestic equity become more attractive to Home investors looking to diversify risk. Equity positions again increase with CPI-indexed bonds compared to welfare-indexed bonds. The overall equity position with FDI is a bit lower under empirically indexed bonds compared to welfarebased bonds. The opposite holds true in Hamano (2015)'s model without FDI. Moreover, as before the Home household is more exposed to foreign bonds when these are CPI-based bonds.

Following Hamano (2015), we explore the possible sources of the high home bias we obtain. For doing so we take a closer look at the conditional correlations that enter the optimal portfolio choices that we derived from the static budget constraint. The results for standard empirical CPI indexed bonds are presented in Table 3.

Table 3 - Conditional correlations - Baseline Model

\begin{tabular}{|c|c|c|c|c|c|}
\hline & $\phi_{w, .}$ & $\phi_{N D, .}$ & $\phi_{N X, .}$ & $\phi_{N D N X}$ & $\phi_{N I N X}$ \\
\hline \multicolumn{6}{|l|}{ FDI } \\
\hline Equity & -0.94 & -0.38 & 0.99 & 0.92 & 0.98 \\
\hline Bonds & 0.15 & -0.16 & -0.99 & -0.96 & -0.99 \\
\hline \multicolumn{6}{|l|}{ No FDI } \\
\hline Equity & -0.87 & -0.31 & - & -0.83 & - \\
\hline Bonds & -0.35 & -0.02 & - & 0.98 & - \\
\hline
\end{tabular}

The entries in the above table give correlations of the relative wages, as well as the variety effects given in the portfolio solutions (50) with the relative return of one asset, conditional on the relative return of the other asset. The definition of the conditional returns is given by

$$
\phi_{x, y}=\rho_{x y \mid z}=\frac{\rho_{x y}-\rho_{x z} \rho z y}{\sqrt{1-\rho_{x z}^{2}} \sqrt{1-\rho_{z y}^{2}}} .
$$

\footnotetext{
${ }^{11}$ Intuitively, there is risk related with the number of foreign varieties that are available in future periods, more varieties for instance imply higher consumption spending on these varieties in future periods. Since foreign goods are denominated in foreign currency exposure to foreign bonds reduces consumption spending risk in foreign currency and therefore hedges against fluctuations in the real exchange rate.
} 
For our baseline model with FDI $x$ represents one of the relative differences $R_{w, t}, \hat{N}_{D, t}^{R}$, $\hat{N}_{X, t}^{R}, \hat{N}_{D, t}^{R}-\hat{N}_{X, t}^{R}$ and $\hat{N}_{I, t}^{R}-\hat{N}_{X, t}^{R} \cdot y$ represents $R_{e, t}$ or $R_{b, t}$, while $z$ represents the other asset return, respectively. So for instance, $\phi_{w, e}$ represents the correlation between relative labor income and relative equity returns, conditional on relative bond returns. For the model without FDI, which is analogous to the model of Hamano (2015), $x$ represents one of the relative differences $R_{w, t}, \hat{N}_{D, t}^{R}$, and $\hat{N}_{D, t}^{R}-\hat{N}_{X, t}^{R}$.

Our portfolio equations in a model with FDI differ from the ones obtained by Hamano (2015) in a model without FDI in that they load on additional risk components and furthermore the weights given to these components. Therefore, they are only comparable to a limited degree. In the case where welfare-based bonds can be traded, the equity portfolios in both models only depend on the conditional correlation between wages and equity returns, given the returns on bonds, $\phi_{w, e}$. As in Hamano (2015), the negative value of -0.87 is the main source of the high equity home bias in the model without FDI. The first column of table 3 shows that the presence of FDI further lowers this correlation to -0.94 contributing to higher optimal Home equity holdings. For the case of CPI-based bonds, two sources of risk that equity positions aim to hedge against, the number of domestic firms and the relative number of domestic exporters and FDI firms contribute to a higher equity home bias. This can be seen by the positive partial correlation coefficients $\phi_{N X, e}$ and $\phi_{N I N X, e}$. The partial correlation coefficient on the relative number of domestic firms and domestic exports $\phi_{N D N X, e}$ is also positive, but enters in the portfolio solution with a negative sign. Therefore this margin contributes to a lower home bias. ${ }^{12}$

From the above portfolio intuition we thus expect that the home equity positions in our dynamic model are higher in a model of FDI compared to a model where FDI is not present and also higher in a model where CPI-based bonds are traded compared to one in which bonds are welfare based. This is consistent with the portfolio solution we obtain with our solution algorithm.

Looking at the differences in bond portfolios, we see that the conditional correlation $\phi_{w, b}$ is positive. This is the reason why agents hold less bonds in the economy with CPI based bonds.

A shortfall of the model is the absolute magnitude of the portfolios we find and the fact that in our model the Home household wants to short foreign equity to gain additional exposure to domestic equity. This is at odds with observed data. However, given that Hamano (2015) in a model without FDI also finds optimal Home equity shares above one and our findings for the baseline case without FDI are very similar to those in Hamano (2015), this does not come as a surprise. Our aim in this paper is to show that the presence of FDI raises the optimal equity home bias in a DSGE model with endogenous selection

\footnotetext{
${ }^{12}$ Since the coefficients on these terms are not directly comparable across models, we only compare them qualitatively and not in terms of their magnitude.
} 
into internationalization modes of production, as is suggested in the empirical work by (Cai and Warnock, 2012). To make the theoretical model match the empirical data to a realistic extend the modeling framework has to be refined. Nonetheless, the direction in which portfolios move in our model in the presence of FDI is a valuable theoretical and qualitative contribution.

\subsection{Sensitivity Analysis}

Figure 1 shows the sensitivity analysis of the portfolio solution we conduct with respect to different parameter choices. In particular, we vary the parameters of the CES demand aggregator, $\alpha_{1}$ and $\alpha_{2}$, as well as the elasticities of substitution among varieties, $\sigma$ and between Home and Foreign goods $\omega$. As a reminder, their standard calibration used for the results presented above is $\alpha_{1}=0.7, \alpha_{2}=0.15, \sigma=3.8$ and $\omega=2$. In figure 1 this standard calibration is represented by the dots. The $\mathrm{x}$-axis in the graphs contained in the figure represent the variation in the respective parameters, while the $\mathrm{y}$-axis represents the respective optimal domestic equity holdings if we vary the respective parameter, keeping all other parameters at their baseline calibration.
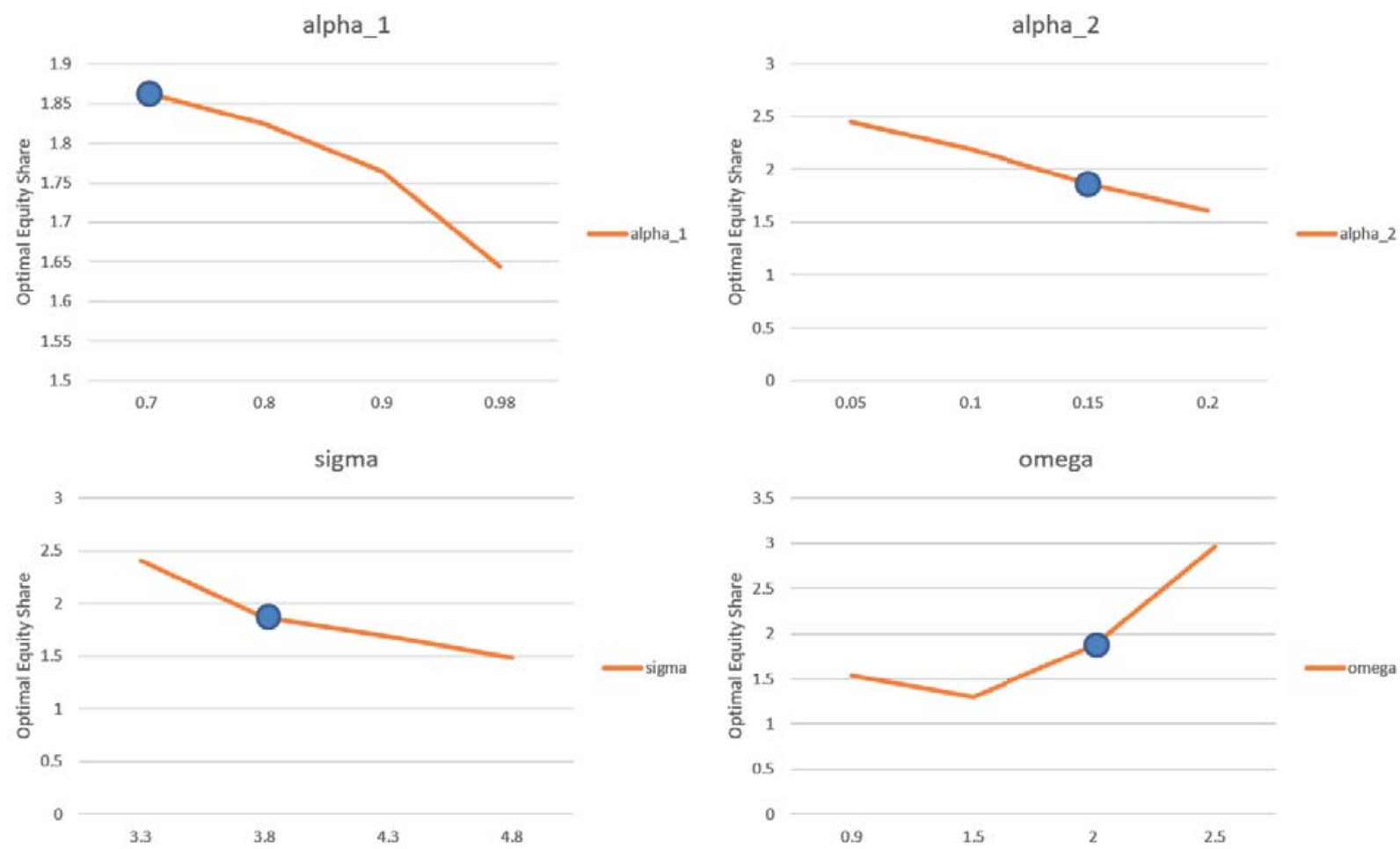

Figure 1 - Sensitivity Analysis

The upper left panel corresponding to the weight of domestically produced goods $\alpha_{1}$ in the demand aggregator shows that the optimal domestic equity share falls with the consumption bias for purely domestically produced goods, this reflects the fact that internationalization of a firm together with a higher preference for the goods it provides through both 
exporting and FDI activity (represented by a fall in $\alpha_{1}$ ) makes it less prone to domestic shocks alone and increases its diversification benefits for domestic investors. At the same time, as shown in the upper right panel, a rise in the weight of imported goods $\alpha_{2}$ also leads to a falling optimal domestic equity position, reflecting that a further increase in FDI preference and activity (represented by a fall in $\alpha_{2}$ ) lead to even higher diversification gains, just as our theory predicts. The lower two panels show the robustness check with respect to the two elasticities of substitution. The left panel shows that the higher the elasticity of substitution between varieties, the lower the optimal home equity position as it becomes more optimal to diversify internationally as individual variety profits become more elastic. The right panel shows that if Home and Foreign goods are complements $(\omega>1)$, the higher the elastcity of substitution between Home and Foreign goods, the higher the optimal Home equity position as Home and Foreign production shocks induce less variability in consumption and welfare. If Home and Foreign goods are substitutes $(\omega<1)$ the opposite holds true. Concerning the level of Home bias evident across these portfolio positions it remains strongly biased towards Home equity in comparison to Foreign equity.

\section{Conclusion}

In this paper, we investigate two questions: How does the degree of internationalization of a country's firms influence the equity investment choices of its households, and how does it affect the widely observed equity home bias? Our rational is that in addition to being prone to the economic conditions of their home country, internationally active firms also depend on the economic conditions of other countries they operate in. Thus the shares of multinational firms provide a higher diversification benefit to investors than investing in a firm that is operating solely nationally. In a DSGE model that includes the endogenous choice of firms to become internationally active through either exports or foreign direct investment (FDI), we find that indeed the optimal equity holdings of agents are more strongly biased towards domestic firms than in a model with trade only. Our finding indicates that international diversification is not as bad as empirical measures of the equity home bias suggest and that the international activity of firms should be taken into account when calculating empirical measures of the equity home bias. 


\section{References}

Backus, David K, Patrick J Kehoe, and Finn E Kydland (1992), "International Real Business Cycles." Journal of Political Economy, 100, 745-75.

Baxter, Marianne and Urban J Jermann (1997), "The International Diversification Puzzle Is Worse Than You Think." American Economic Review, 87, 170-80.

Benassy, Jean-Pascal (1996), "Taste for variety and optimum production patterns in monopolistic competition." Economics Letters, 52, 41-47.

Broda, Christian and David W. Weinstein (2004), "Variety Growth and World Welfare." American Economic Review, 94, 139-144.

Cai, Fang and Francis E. Warnock (2012), "Foreign exposure through domestic equities." Finance Research Letters, 9, 8-20.

Coeurdacier, Nicolas and Pierre-Olivier Gourinchas (2011), "When Bonds Matter: Home Bias in Goods and Assets."

Coeurdacier, Nicolas, Robert Kollmann, and Philippe Martin (2010), "International portfolios, capital accumulation and foreign assets dynamics." Journal of International Economics, 80, 100-112.

Coeurdacier, Nicolas and Hélène Rey (2013), "Home Bias in Open Economy Financial Macroeconomics." Journal of Economic Literature, 51, 63-115.

Contessi, Silvio (2010), "How Does Multinational Production Change International Comovement?" Mimeo.

Devereux, Michael B. and Alan Sutherland (2010), "Country portfolio dynamics." Journal of Economic Dynamics and Control, 34, 1325-1342.

Devereux, Michael B. and Alan Sutherland (2011), "Country Portfolios In Open Economy Macro-Models." Journal of the European Economic Association, 9, 337-369.

Ghironi, Fabio and Marc J. Melitz (2005), "International Trade and Macroeconomic Dynamics with Heterogeneous Firms." The Quarterly Journal of Economics, 120, 865-915.

Ghironi, Fabio and Marketa Halova Wolfe (2018), "Multinational Production, Risk Sharing,and Home Equity Bias." Mimeo.

Hamano, Masashige (2015), "International equity and bond positions in a dsge model with variety risk in consumption." Journal of International Economics, 96, 212 - 226.

Heathcote, Jonathan and Fabrizio Perri (2013), "The International Diversification Puzzle Is Not as Bad as You Think." Journal of Political Economy, 121, 1108 - 1159. 
Helpman, Elhanan, Marc J. Melitz, and Stephen R. Yeaple (2004), "Export Versus FDI with Heterogeneous Firms." American Economic Review, 94, 300-316.

Lucas, Robert Jr. (1982), "Interest rates and currency prices in a two-country world." Journal of Monetary Economics, 10, 335-359.

Melitz, Marc J. (2003), "The Impact of Trade on Intra-Industry Reallocations and Aggregate Industry Productivity." Econometrica, 71, 1695-1725.

Obstfeld, Maurice and Kenneth Rogoff (2001), "The Six Major Puzzles in International Macroeconomics: Is There a Common Cause?"

OECD (2018), "Measuring MNEs using Big Data: The OECD Analytical Database on Individual Multinationals and their Affiliates." Technical report, Organisation for Economic Co-operation and Development.

Schmitt-Grohe, Stephanie and Martin Uribe (2003), "Closing small open economy models." Journal of International Economics, Elsevier, 61, 163-185.

van Wincoop, Eric and Francis E. Warnock (2010), "Can trade costs in goods explain home bias in assets?" Journal of International Money and Finance, 29, 1108-1123. 


\section{Appendix}

\subsection{Multinational enterprises from the OECD's ADIMA}

Multinational enterprises from the OECD's ADIMA underlying Table 1

France: Carrefour SA, Engie SA, Peugeot SA, Renault SA, Total SA;

Germany: BASF SE, Bayer AG, Bayerische Motoren Werke AG, Ceconomy AG, Daimler AG, Deutsche Post AG, Deutsche Telekom AG, Siemens AG, Uniper SE, Volkswagen AG; Japan: Aeon Co Ltd, Hitachi Ltd, Honda Motor Co Ltd, JXTG Holdings Inc, Marubeni Corp, Mitsubishi Corp, Nippon Telegraph and Telephone Corp, Nissan Motor Co Ltd, Panasonic Corp, SoftBank Group Corp, Sony Corp, Toyota Motor Corp;

Switzerland: Nestle SA, Novartis AG, Roche Holding AG;

United States: AT\&T Inc, Aetna Inc, Alphabet Inc, Amazon.com Inc, Apple Inc, Archer Daniels Midland Co, Boeing Co, CVS Health Corp, Cardinal Health Inc, Comcast Corp, Costco Wholesale Corp, Dell Technologies Inc, DowDuPont Inc, Express Scripts Holding Co, Exxon Mobil Corp, FedEx Corp, Ford Motor Co, General Electric Co, General Motors Co, HP Inc, Hewlett Packard Enterprise Co, Home Depot Inc, Intel Corp, International Business Machines Corp, Johnson \& Johnson, McKesson Corp, Microsoft Corp, PepsiCo Inc, Pfizer Inc, Phillips 66, Procter \& Gamble Co, Sysco Corp, United Parcel Service Inc, United Technologies Corp, UnitedHealth Group Inc, Valero Energy Corp, Wal-Mart Stores Inc, Walgreens Boots Alliance Inc, Walt Disney Co.

\subsection{The equation system}

- Price indices:

$$
\begin{array}{r}
{\left[\alpha_{1} \rho_{H, t}^{1-\omega}+\alpha_{2} \rho_{X, t}^{1-\omega}+\left(1-\alpha_{1}-\alpha_{2}\right) \rho_{F D I, t}^{1-\omega}\right]=1} \\
{\left[\alpha_{1} \rho_{H, t}^{* 1-\omega}+\alpha_{2} \rho_{X, t}^{* 1-\omega}+\left(1-\alpha_{1}-\alpha_{2}\right) \rho_{F D I, t}^{* 1-\omega}\right]=1}
\end{array}
$$

- Price indices - Domestic Components:

$$
\begin{aligned}
& \rho_{H, t}=N_{D, t}^{-\psi} \tilde{\rho}_{D, t} \\
& \rho_{H, t}^{*}=N_{D, t}^{*-\psi} \tilde{\rho}_{D, t}^{*}
\end{aligned}
$$

- Price indices - Imported Components:

$$
\begin{aligned}
& \rho_{X, t}=N_{X, t}^{*-\psi} \tilde{\rho}_{X, t}^{*} \\
& \rho_{X, t}^{*}=N_{D, t}^{-\psi} \tilde{\rho}_{X, t}
\end{aligned}
$$


- Price indices - FDI Components:

$$
\begin{aligned}
& \rho_{F D I, t}=N_{I, t}^{*-\psi} \tilde{\rho}_{I, t}^{*} \\
& \rho_{F D I, t}^{*}=N_{I, t}^{-\psi} \tilde{\rho}_{I, t}
\end{aligned}
$$

- Firm level pricing - Domestically sold goods:

$$
\begin{aligned}
& \tilde{\rho}_{D, t}=\frac{\sigma}{\sigma-1} \frac{w_{t}}{Z_{t} \tilde{z}_{D, t}} \\
& \tilde{\rho}_{D, t}^{*}=\frac{\sigma}{\sigma-1} \frac{w_{t}^{*}}{Z_{t}^{*} \tilde{z}_{D, t}^{*}}
\end{aligned}
$$

- Firm level pricing - Exported goods:

$$
\begin{aligned}
& \tilde{\rho}_{X, t}=\frac{\tau_{t}}{Q_{t}} \frac{\sigma}{\sigma-1} \frac{w_{t}}{Z_{t} \tilde{z}_{X, t}} \\
& \tilde{\rho}_{X, t}^{*}=\tau_{t}^{*} Q_{t} \frac{\sigma}{\sigma-1} \frac{w_{t}^{*}}{Z_{t}^{*} \tilde{z}_{X, t}^{*}}
\end{aligned}
$$

- Firm level pricing - FDI goods sold by foreign affiliates:

$$
\begin{aligned}
& \tilde{\rho}_{I, t}=\frac{\sigma}{\sigma-1} \frac{w_{t}^{*}}{Z_{t}^{*} \tilde{z}_{I, t}} \\
& \tilde{\rho}_{I, t}^{*}=\frac{\sigma}{\sigma-1} \frac{w_{t}}{Z_{t} \tilde{z}_{I, t}^{*}}
\end{aligned}
$$

- Total average profits:

$$
\begin{aligned}
& \tilde{d}_{t}=\tilde{d}_{D, t}+\frac{N_{X, t}}{N_{D, t}} \tilde{d}_{X, t}+\frac{N_{I, t}}{N_{D, t}} \tilde{d}_{I, t} \\
& \tilde{d}_{t}^{*}=\tilde{d}_{D, t}^{*}+\frac{N_{X, t}^{*}}{N_{D, t}^{*}} \tilde{d}_{X, t}^{*}+\frac{N_{I, t}^{*}}{N_{D, t}^{*}} \tilde{d}_{I, t}^{*}
\end{aligned}
$$

- Average profits from domestically sold goods:

$$
\begin{aligned}
\tilde{d}_{D, t} & =\frac{1}{\sigma} N_{D, t}^{\psi(\omega-1)-1} \tilde{\rho}_{D, t}^{1-\omega} \alpha_{1} C_{t} \\
\tilde{d}_{D, t}^{*} & =\frac{1}{\sigma} N_{D, t}^{* \psi(\omega-1)-1} \tilde{\rho}_{D, t}^{* 1-\omega} \alpha_{1} C_{t}^{*}
\end{aligned}
$$

- Average profits from exported goods:

$$
\begin{aligned}
& \tilde{d}_{X, t}=\frac{1}{\sigma} Q_{t} N_{X, t}^{\psi(\omega-1)-1} \tilde{\rho}_{X, t}^{1-\omega} \alpha_{2}^{*} C_{t}^{*}-\frac{w_{t} f_{X, t}}{Z_{t}} \\
& \tilde{d}_{X, t}^{*}=\frac{1}{\sigma} \frac{1}{Q_{t}} N_{X, t}^{* \psi(\omega-1)-1} \tilde{\rho}_{X, t}^{* 1-\omega} \alpha_{2} C_{t}-\frac{w_{t}^{*} f_{X, t}^{*}}{Z_{t}^{*}}
\end{aligned}
$$


- Average profits from FDI goods produced by foreign affiliate:

$$
\begin{aligned}
& \tilde{d}_{I, t}=Q_{t}\left[\frac{1}{\sigma} N_{I, t}^{\psi(\omega-1)-1} \tilde{\rho}_{I, t}^{1-\omega}\left(1-\alpha_{1}-\alpha_{2}\right) C_{t}^{*}-\frac{w_{t}^{*} f_{I, t}^{*}}{Z_{t}^{*}}\right] \\
& \tilde{d}_{I, t}^{*}=\frac{1}{Q_{t}}\left[\frac{1}{\sigma} N_{I, t}^{* \psi(\omega-1)-1} \tilde{\rho}_{I, t}^{* 1-\omega}\left(1-\alpha_{1}-\alpha_{2}\right) C_{t}-\frac{w_{t} f_{I, t}}{Z_{t}}\right]
\end{aligned}
$$

- Free-entry conditions:

$$
\begin{aligned}
\tilde{v}_{t}^{s} & =w_{t} \frac{f_{E, t}}{Z_{E, t}} \\
\tilde{v}_{t}^{s *} & =w_{t}^{*} \frac{f_{E, t}^{*}}{Z_{E, t}^{*}}
\end{aligned}
$$

- Optimal labor supply:

$$
\begin{gathered}
\chi L_{t}^{\frac{1}{\psi}}=w_{t} C_{t}^{-\gamma} \\
\chi L_{t}^{* \frac{1}{\psi}}=w_{t}^{*} C_{t}^{*-\gamma}
\end{gathered}
$$

- Labor market clearing:

$$
\begin{aligned}
& L_{t}=\frac{(\sigma-1)}{w_{t}}\left[N_{D, t} \tilde{d}_{D, t}+N_{X, t} \tilde{d}_{X, t}+N_{I, t}^{*} Q_{t} \tilde{d}_{I, t}^{*}\right]+\frac{\sigma}{Z_{t}}\left[\frac{N_{E, t} f_{E, t}}{\sigma}+N_{X, t} f_{X, t}+N_{I, t}^{*} f_{I, t}\right] \\
& L_{t}^{*}=\frac{(\sigma-1)}{w_{t}^{*}}\left[N_{D, t}^{*} \tilde{d}_{D, t}^{*}+N_{X, t}^{*} \tilde{d}_{X, t}^{*}+N_{I, t} Q_{t}^{-1} \tilde{d}_{I, t}\right]+\frac{\sigma}{Z_{t}^{*}}\left[\frac{N_{E, t}^{*} f_{E, t}^{*}}{\sigma}+N_{X, t}^{*} f_{X, t}^{*}+N_{I, t} f_{I, t}^{*}\right]
\end{aligned}
$$

- Share of exporters:

$$
\begin{aligned}
& \frac{N_{X, t}}{N_{D, t}}=\left(z_{\min }\right)^{k}\left(\tilde{z}_{X, t}^{-k}-\tilde{z}_{I, t}^{-k}\right) \\
& \frac{N_{X, t}^{*}}{N_{D, t}^{*}}=\left(z_{\min }\right)^{* k}\left(\tilde{z}_{X, t}^{*-k}-\tilde{z}_{I, t}^{*-k}\right)
\end{aligned}
$$

- Share of FDI firms:

$$
\begin{aligned}
& \frac{N_{I, t}}{N_{D, t}}=\left(z_{\text {min }}\right)^{k}\left(\tilde{z}_{I, t}\right)^{-k}\left(\frac{k}{k-(\sigma-1)}\right)^{\frac{k}{\sigma-1}} \\
& \frac{N_{I, t}^{*}}{N_{D, t}^{*}}=\left(z_{\text {min }}\right)^{* k}\left(\tilde{z}_{I, t}\right)^{*-k}\left(\frac{k}{k-(\sigma-1)}\right)^{\frac{k}{\sigma-1}},
\end{aligned}
$$


- Zero-profit export cutoff:

$$
\begin{aligned}
& \left.\tilde{d}_{X, t}=\left[\left(\nabla \frac{\left(\frac{f_{X, t}^{*}}{\alpha_{2}^{*}}\right)^{\frac{k-\sigma+1}{1-\omega}}-\left[\left(T O L_{t}\right)^{\omega} \tau_{t}^{1-\omega}\left(\frac{f_{I, t}^{*}}{1-\alpha_{1}^{*}-\alpha_{2}^{*}}\right)\left(\frac{N_{X, t}}{N_{I, t}}\right)^{(\psi(\omega-1)-1)}\right]^{\frac{k-\sigma+1}{1-\omega}}}{\left(\frac{f_{X, t}}{\alpha_{2}^{*}}\right)^{\frac{k}{1-\omega}}-\left[\left(T O L_{t}\right)^{\omega}\left(\frac{f_{I, t}^{*}}{1-\alpha_{1}^{*}-\alpha_{2}^{*}}\right) \tau_{t}^{1-\omega}\left(\frac{N_{X, t}}{N_{I, t}}\right)^{(\psi(\omega-1)-1)}\right]^{\frac{k}{1-\omega}}}\right]\right)^{\frac{\omega-1}{\sigma-1}} \alpha_{2}^{*}-f_{X, t}\right] \frac{w_{t}}{Z_{t}} \\
& \tilde{d}_{X, t}^{*}=\left[\left(\nabla\left[\frac{\left(\frac{f_{X, t}^{*}}{\alpha_{2}}\right)^{\frac{k-\sigma+1}{1-\omega}}-\left[\left(T O L_{t}\right)^{-\omega} \tau_{t}^{1-\omega}\left(\frac{f_{I, t}}{1-\alpha_{1}-\alpha_{2}}\right)\left(\frac{N_{X, t}^{*}}{N_{I, t}^{*}}\right)^{(\psi(\omega-1)-1)}\right]^{\frac{k-\sigma+1}{1-\omega}}}{\left(\frac{f_{X, t}^{*}}{\alpha_{2}}\right)^{\frac{k}{1-\omega}}-\left[\left(T O L_{t}\right)^{-\omega}\left(\frac{f_{I, t}}{1-\alpha_{1}-\alpha_{2}}\right) \tau_{t}^{1-\omega}\left(\frac{N_{X, t}^{*}}{N_{I, t}^{*}}\right)^{(\psi(\omega-1)-1)}\right]^{\frac{k}{1-\omega}}}\right]\right)^{\frac{\omega-1}{\sigma-1}} \alpha_{2}-f_{X, t}^{*}\right] \frac{w_{t}^{* *}}{Z_{t}}
\end{aligned}
$$

- Zero-profit FDI cutoff:

$$
\begin{aligned}
& \tilde{d}_{I, t}=Q_{t}\left(\nabla^{\frac{1-\omega}{1-\sigma}}-1\right) \frac{w_{t}^{*}}{Z_{t}^{*}} f_{I, t}^{*} \\
& \tilde{d}_{I, t}^{*}=\frac{1}{Q_{t}}\left(\nabla^{\frac{1-\omega}{1-\sigma}}-1\right) \frac{w_{t}}{Z_{t}} f_{I, t}
\end{aligned}
$$

- Law of motion of domestic firms:

$$
\begin{aligned}
& N_{D, t+1}=(1-\delta)\left(N_{D, t}+N_{E, t}\right) \\
& N_{D, t+1}^{*}=(1-\delta)\left(N_{D, t}^{*}+N_{E, t}^{*}\right)
\end{aligned}
$$

- Terms of Labor:

$$
T O L_{t}=\left(\frac{w_{t}}{Z_{t} Q_{t}}\right)^{-1}\left(\frac{w_{t}^{*}}{Z_{t}^{*}}\right)
$$

- Definitions of returns:

$$
\begin{aligned}
& r_{h, t}^{s}=(1-\delta) \frac{\tilde{v}_{t}^{s}+\tilde{d}_{t}}{\tilde{v}_{t-1}^{s}} \\
& r_{f, t}^{s}=(1-\delta) \frac{\tilde{v}_{t}^{s *}+\tilde{d}_{t}^{*}}{\tilde{v}_{t-1}^{s *}} \frac{Q_{t}}{Q_{t-1}} \\
& r_{h, t}^{b}=\frac{v_{t}^{b}+d_{t}^{b}}{v_{t-1}^{b}} \\
& r_{f, t}^{b}=\frac{v_{t}^{b *}+d_{t}^{b *}}{v_{t-1}^{b *}} \frac{Q_{t}}{Q_{t-1}}
\end{aligned}
$$


- Euler Home and Foreign:

$$
C_{t}^{-\gamma-\nu} E_{t}\left[C_{t+1}^{-\gamma}\right]=C_{t}^{*-\gamma-\nu} E_{t}\left[* C_{t+1}^{-\gamma} \frac{Q_{t}}{Q_{t+1}}\right]
$$

- Euler Home and Foreign:

$$
\begin{aligned}
& 1=\bar{\beta} C_{t}^{\gamma-\nu} E_{t}\left\{\left(C_{t+1}\right)^{-\gamma} r_{h, t+1}^{s}\right\} \\
& 1=\bar{\beta} C_{t}^{\gamma-\nu} E_{t}\left\{\left(C_{t+1}\right)^{-\gamma} r_{f, t+1}^{s}\right\} \\
& 1=\bar{\beta} C_{t}^{\gamma-\nu} E_{t}\left\{\left(C_{t+1}\right)^{-\gamma} r_{h, t+1}^{b}\right\} \\
& 1=\bar{\beta} C_{t}^{\gamma-\nu} E_{t}\left\{\left(C_{t+1}\right)^{-\gamma} r_{f, t+1}^{b}\right\}
\end{aligned}
$$

- Expected Excess Returns:

$$
\begin{aligned}
& r_{h x, t}^{s}=r_{h, t}^{s}-r_{h, t}^{b} \\
& r_{f x, t}^{s}=r_{f, t}^{s}-r_{h, t}^{b} \\
& r_{f x, t}^{b}=r_{f, t}^{b}-r_{h, t}^{b}
\end{aligned}
$$

- Definitions of income:

$$
\begin{gathered}
Y_{t}=w_{t} L_{t}+N_{D, t} \tilde{d}_{t}-N_{E, t} \tilde{v}_{t}^{s} \\
Y_{t}^{*}=w_{t}^{*} L_{t}^{*}+N_{D, t}^{*} \tilde{d}_{t}^{*}-N_{E, t}^{*} \tilde{v}_{t}^{s *}
\end{gathered}
$$

- Net exports:

$$
N X_{t}=\frac{1}{2}\left[\left(Y_{t}-Q_{t} Y_{t}^{*}\right)-\left(C_{t}-Q_{t} C_{t}^{*}\right)\right]
$$

- Net foreign assets:

$$
N F A_{t+1}=N X_{t}+N F A_{t} r_{h, t}^{b}+a_{f, t-1} r_{f x, t}^{s}-a_{h, t-1}^{* s} r_{h x, t}^{s}+a_{f, t-1}^{b} r_{f x, t}^{b}
$$

For the case of welfare indexed bonds bond dividends are $d_{t}^{b}=d_{t}^{* b}=1$, the bond returns become:

$$
\begin{aligned}
& r_{h, t}^{b}=\frac{v_{t}^{b}+1}{v_{t-1}^{b}} \\
& r_{f, t}^{b}=\frac{v_{t}^{b *}+1}{v_{t-1}^{b *}} \frac{Q_{t}}{Q_{t-1}}
\end{aligned}
$$




\section{BANCO DE ESPAÑA PUBLICATIONS}

\section{WORKING PAPERS}

1910 JAMES COSTAIN, ANTON NAKOV and BORJA PETIT: Monetary policy implications of state-dependent prices and wages

1911 JAMES CLOYNE, CLODOMIRO FERREIRA, MAREN FROEMEL and PAOLO SURICO: Monetary policy, corporate finance and investment.

1912 CHRISTIAN CASTRO and JORGE E. GALÁN: Drivers of productivity in the Spanish banking sector: recent evidence.

1913 SUSANA PÁRRAGA RODRÍGUEZ: The effects of pension-related policies on household spending.

1914 MÁXIMO CAMACHO, MARÍA DOLORES GADEA and ANA GÓMEZ LOSCOS: A new approach to dating the reference cycle.

1915 LAURA HOSPIDO, LUC LAEVEN and ANA LAMO: The gender promotion gap: evidence from Central Banking.

1916 PABLO AGUILAR, STEPHAN FAHR, EDDIE GERBA and SAMUEL HURTADO: Quest for robust optimal macroprudential policy.

1917 CARMEN BROTO and MATÍAS LAMAS: Is market liquidity less resilient after the financial crisis? Evidence for US treasuries.

1918 LAURA HOSPIDO and CARLOS SANZ: Gender Gaps in the Evaluation of Research: Evidence from Submissions to Economics Conferences.

1919 SAKI BIGIO, GALO NUÑO and JUAN PASSADORE: A framework for debt-maturity management.

1920 LUIS J. ÁLVAREZ, MARÍA DOLORES GADEA and ANA GÓMEZ-LOSCOS: Inflation interdependence in advanced economies.

1921 DIEGO BODAS, JUAN R. GARCÍA LÓPEZ, JUAN MURILLO ARIAS, MATÍAS J. PACCE, TOMASA RODRIGO LÓPEZ, JUAN DE DIOS ROMERO PALOP, PEP RUIZ DE AGUIRRE, CAMILO A. ULLOA and HERIBERT VALERO LAPAZ: Measuring retail trade using card transactional data.

1922 MARIO ALLOZA and CARLOS SANZ: Jobs multipliers: evidence from a large fiscal stimulus in Spain.

1923 KATARZYNA BUDNIK, MASSIMILIANO AFFINITO, GAIA BARBIC, SAIFFEDINE BEN HADJ, ÉDOUARD CHRÉTIEN, HANS DEWACHTER, CLARA ISABEL GONZÁLEZ, JENNY HU, LAURI JANTUNEN, RAMONA JIMBOREAN, OTSO MANNINEN, RICARDO MARTINHO, JAVIER MENCÍA, ELENA MOUSARRI, LAURYNAS NARUŠEVIČIUS, GIULIO NICOLETTI, MICHAEL O'GRADY, SELCUK OZSAHIN, ANA REGINA PEREIRA, JAIRO RIVERA-ROZO, CONSTANTINOS TRIKOUPIS, FABRIZIO VENDITTI and SOFÍA VELASCO: The benefits and costs of adjusting bank capitalisation: evidence from Euro Area countries.

1924 MIGUEL ALMUNIA and DAVID LÓPEZ-RODRÍGUEZ: The elasticity of taxable income in Spain: 1999-2014.

1925 DANILO LEIVA-LEON and LORENZO DUCTOR: Fluctuations in global macro volatility.

1926 JEF BOECKX, MAARTEN DOSSCHE, ALESSANDRO GALESI, BORIS HOFMANN and GERT PEERSMAN: Do SVARs with sign restrictions not identify unconventional monetary policy shocks?

1927 DANIEL DEJUÁN and JUAN S. MORA-SANGUINETTI: Quality of enforcement and investment decisions. Firm-level evidence from Spain.

1928 MARIO IZQUIERDO, ENRIQUE MORAL-BENITO and ELVIRA PRADES: Propagation of sector-specific shocks within Spain and other countries.

1929 MIGUEL CASARES, LUCA DEIDDA and JOSÉ E. GALDÓN-SÁNCHEZ: On financial frictions and firm market power.

1930 MICHAEL FUNKE, DANILO LEIVA-LEON and ANDREW TSANG: Mapping China's time-varying house price landscape.

1931 JORGE E. GALÁN and MATÍAS LAMAS: Beyond the LTV ratio: new macroprudential lessons from Spain.

1932 JACOPO TIMINI: Staying dry on Spanish wine: the rejection of the 1905 Spanish-Italian trade agreement.

1933 TERESA SASTRE and LAURA HERAS RECUERO: Domestic and foreign investment in advanced economies. The role of industry integration.

1934 DANILO LEIVA-LEON, JAIME MARTÍNEZ-MARTÍN and EVA ORTEGA: Exchange rate shocks and inflation comovement in the euro area.

1935 FEDERICO TAGLIATI: Child labor under cash and in-kind transfers: evidence from rural Mexico.

1936 ALBERTO FUERTES: External adjustment with a common currency: the case of the euro area.

1937 LAURA HERAS RECUERO and ROBERTO PASCUAL GONZÁLEZ: Economic growth, institutional quality and financial development in middle-income countries

1938 SILVIA ALBRIZIO, SANGYUP CHOI, DAVIDE FURCERI and CHANSIK YOON: International Bank Lending Channel of Monetary Policy.

1939 MAR DELGADO-TÉLLEZ, ENRIQUE MORAL-BENITO and JAVIER J. PÉREZ: Outsourcing and public expenditure: an aggregate perspective with regional data 
1940 MYROSLAV PIDKUYKO: Heterogeneous spillovers of housing credit policy.

1941 LAURA ÁLVAREZ ROMÁN and MIGUEL GARCÍA-POSADA GÓMEZ: Modelling regional housing prices in Spain.

1942 STÉPHANE DÉES and ALESSANDRO GALESI: The Global Financial Cycle and US monetary policy in an interconnected world.

1943 ANDRÉS EROSA and BEATRIZ GONZÁLEZ: Taxation and the life cycle of firms.

1944 MARIO ALLOZA, JESÚS GONZALO and CARLOS SANZ: Dynamic effects of persistent shocks.

1945 PABLO DE ANDRÉS, RICARDO GIMENO and RUTH MATEOS DE CABO: The gender gap in bank credit access.

1946 IRMA ALONSO and LUIS MOLINA: The SHERLOC: an EWS-based index of vulnerability for emerging economies.

1947 GERGELY GANICS, BARBARA ROSSI and TATEVIK SEKHPOSYAN: From Fixed-event to Fixed-horizon Density Forecasts: Obtaining Measures of Multi-horizon Uncertainty from Survey Density Forecasts.

1948 GERGELY GANICS and FLORENS ODENDAHL: Bayesian VAR Forecasts, Survey Information and Structural Change in the Euro Area.

2001 JAVIER ANDRÉS, PABLO BURRIEL and WENYI SHEN: Debt sustainability and fiscal space in a heterogeneous Monetary Union: normal times vs the zero lower bound.

2002 JUAN S. MORA-SANGUINETTI and RICARDO PÉREZ-VALLS: ¿Cómo afecta la complejidad de la regulación a la demografía empresarial? Evidencia para España.

2003 ALEJANDRO BUESA, FRANCISCO JAVIER POBLACIÓN GARCÍA and JAVIER TARANCÓN: Measuring the procyclicality of impairment accounting regimes: a comparison between IFRS 9 and US GAAP.

2004 HENRIQUE S. BASSO and JUAN F. JIMENO: From secular stagnation to robocalypse? Implications of demographic and technological changes.

2005 LEONARDO GAMBACORTA, SERGIO MAYORDOMO and JOSÉ MARÍA SERENA: Dollar borrowing, firm-characteristics, and FX-hedged funding opportunities.

2006 IRMA ALONSO ÁLVAREZ, VIRGINIA DI NINO and FABRIZIO VENDITTI: Strategic interactions and price dynamics in the global oil market.

2007 JORGE E. GALÁN: The benefits are at the tail: uncovering the impact of macroprudential policy on growth-at-risk.

2008 SVEN BLANK, MATHIAS HOFFMANN and MORITZ A. ROTH: Foreign direct investment and the equity home bias puzzle.

\section{BANCODEESPAÑA}

Eurosistema
Unidad de Servicios Generales

Alcalá, 48 - 28014 Madrid

E-mail: publicaciones@bde.es www.bde.es 